\title{
Novel CFCs-Substitutes Recommended by EPA (Hydrofluorocarbon-245fa and Hydrofluoroether-7100): Ion Chemistry in Air Plasma and Reactions with Atmospheric Ions
}

\author{
Ester Marotta* and Cristina Paradisi \\ INTM del CNR—Sezione di Padova, Dipartimento di Scienze Chimiche, Università di Padova, Padova, Italy \\ R. Graham Cooks \\ Department of Chemisty, Purdue University, West Lafayette, Indiana, USA
}

\begin{abstract}
The ion chemistry of the title compounds, a nonafluorobutyl methyl ether and a hydrofluoropropane, is elucidated by a combination of studies using atmospheric pressure ionization mass spectrometry and triple quadrupole mass spectrometry. In the positive ion mode, the hydrofluoroether readily forms an $\left[\mathrm{M}-\mathrm{F}^{+}\right.$ion, attributable to hydronium ion induced dehydrofluorination, the product of which can be further hydrated to give a protonated hydrofluoroester. By contrast, the hydrofluoropropane does not react with the hydronium ion but rather gives hydrofluoroalkenylium cations via $\mathrm{H}$ atom and $\mathrm{F}$ atom abstraction by the dioxygen radical cation. In the negative ion mode, the fluorobutyl methyl ether undergoes dissociative electron capture with $\mathrm{O}_{2}^{-*}, \mathrm{O}_{2}^{-\cdot}\left(\mathrm{H}_{2} \mathrm{O}\right), \mathrm{O}_{3}^{-*}$, and $\mathrm{NO}_{2}^{-}$to generate the fluorobutoxy anion, which can dissociate by $\mathrm{CF}_{2}=\mathrm{O}$ loss to give the perfluorocarbanion when the precursor ions are internally excited. The hydrofluoropropane reacts readily with common atmospheric anions to form molecular complexes with $\mathrm{F}^{-}, \mathrm{O}_{2}^{--}$, and $\mathrm{O}_{3}^{--}$and the strongly $\mathrm{H}$-bonded species, $\mathrm{O}_{2}^{-\cdot}(\mathrm{HF})$ and $\mathrm{F}^{-}(\mathrm{HF})$. Interestingly, isomeric pentafluoropropanes form in the reaction with $\mathrm{O}_{2}^{-}$, either $\mathrm{O}_{2}^{-}(\mathrm{HF})$ or $\mathrm{F}^{-}(\mathrm{HF})$, depending on the specific pattern of the fluoro substitution. (J Am Soc Mass Spectrom 2005, 16, 1081-1092) () 2005 American Society for Mass Spectrometry
\end{abstract}

$\mathrm{F}$ ollowing the 1987 Montreal Protocol, participating countries proceeded to phase out chlorine containing fluids, widely used in many industrial and consumer applications (refrigeration, foaming, aerosol propulsion), for their effect on the depletion of the Earth's ozone layer [1]. The search for nonchlorinated substitutes for hydrochlorocarbons (HCCs), hydrochlorofluorocarbons (HCFCs), and chlorofluorocarbons (CFCs), has focused primarily on fluorine containing chemicals, including hydrofluorocarbons (HFCs) and hydrofluoroethers (HFEs). In contrast to CFCs, HFCs and HFEs are considered ozone-safe substances for their lack of chlorine and bromine substituents, which, released as free atoms, are known to strongly interfere with the ozone cycle. Moreover, thanks to their hydrogen content, HFCs and HFEs are

Published online May 25, 2005

Address reprint requests to Prof. Cristina Paradisi, Dipartamento di Scienze Chimiche, Università di Padova, via Marzolo 1, 35131 Padova, Italy. E-mail: cristina.paradisi@unipd.it

* Also at the Department of Chemistry, Purdue University, West Lafayette, IN, USA. expected to undergo reactions with free radicals in the well-mixed lower layer of the Earth's atmosphere, the troposphere, which will prevent them from reaching the stratosphere.

When introducing new compounds of synthesis for use in applications, it is mandatory to know in detail their behavior and reactivity under different experimental conditions to which they might become exposed while in use or when released into the environment. The lifetime in the atmosphere of hydrogen-containing fluorinated compounds is governed essentially by their reaction with the hydroxyl radical in the troposphere and lower stratosphere [1]. Therefore, ion/molecule reactions occurring in the mesosphere and lower thermosphere should not have an effect on the atmospheric lifetimes of these compounds. Nevertheless, the gas phase ion chemistry and specific ion/molecule reactions of such volatile organic compounds is of interest, both for fundamental knowledge and for applicationoriented research and development related to analytical chemistry (e.g., electron capture detectors for gas chromatographs, CIMS instruments for fast-response chem- 
ical sensors) and plasma technologies (e.g., plasma processing of materials). Specifically, novel nonthermal plasma-based technologies are currently being developed for the removal of VOCs (volatile organic compounds) from contaminated air [2]. A major focus of our research in this field deals with the ionic reactions occurring in such air plasmas, which can be conveniently produced by corona discharges at atmospheric pressure, and investigated by means of APCI-MS analysis [3-7]. Finally, it is worth mentioning that the interest in such novel plasma-based treatment processes is also attributable to the possibility of abatement of ozone-safe compounds which are, however, implicated as greenhouse gases.

The present account reports the results of an investigation of positive and negative ions formed from fluoroether HFE-7100 (nonafluorobutyl methyl ether composed of two inseparable isomers, $\left(\mathrm{CF}_{3}\right)_{2} \mathrm{CFCF}_{2} \mathrm{OCH}_{3}$ and $\left.\mathrm{CF}_{3}\left(\mathrm{CF}_{2}\right)_{3} \mathrm{OCH}_{3}\right)$, and fluoropropane HFC-245fa (1,1,1,3,3-pentafluoropropane) in air plasmas at atmospheric pressure. Both HFE-7100 and HFC-245fa were recently recommended by EPA as new viable substitutes for CFCs [8]. Their gas phase ion chemistry is so far unreported.

Two experimental approaches were used in this investigation to study the ionic reactions of the title compounds in air. First, experiments were conducted with a single analyzer APCI-MS apparatus to gain essential information on the ions which are produced from the investigated compounds within the air plasma. Such experiments usually allow for the inference of major ionization and fragmentation routes and other important ion/molecule reactions. An obvious limitation of this experimental set-up is the lack of MS/MS capabilities: the recorded APCI spectra are due to all the products of the reactions of the organic compounds with all the background ions. To gain a better insight into the ion chemistry of the title compounds in air, their reactivity towards specific atmospheric ions $\left(\mathrm{H}_{3} \mathrm{O}^{+}, \mathrm{O}_{2}^{--}, \mathrm{O}_{3}^{-\cdot}, \mathrm{NO}_{2}^{-}\right.$, and their hydrates) was then extensively investigated using an APCI source coupled to a triple quadrupole mass spectrometer. The APCI source was fed with air to produce the reactant ions, which were mass-selected and allowed to react with the fluorocompound in the collision cell of the triple quadrupole. The results from the two experimental approaches provide an integrated picture of the atmospheric ion chemistry of the title compounds. Additional results obtained with a third compound, the fluoropropane HFC-245ca (1,1,2,2,3-pentafluoropropane), isomeric with HFC-245fa, are also reported for comparison.

\section{Experimental}

\section{Materials}

HFE-7100 [nonafluorobutyl methyl ether composed of two inseparable isomers, $\left(\mathrm{CF}_{3}\right)_{2} \mathrm{CFCF}_{2} \mathrm{OCH}_{3}$ and
$\mathrm{CF}_{3}\left(\mathrm{CF}_{2}\right)_{3} \mathrm{OCH}_{3}$, purity 99\%] and HFC-245ca $(1,1,2,2,3-$ pentafluoropropane, purity $99 \%$ ) were commercial R.P. products of Aldrich (St. Louis, MO), HFC-245fa (1,1,1,3,3-pentafluoropropane, purity 98\%) was from SynQuest Laboratories (Alachua, FL); they were used as received. High purity synthetic air, with a specified $\mathrm{H}_{2} \mathrm{O}$ impurity of less than 5 ppm, was used as background gas.

\section{Instrumentation and Procedures}

APCI spectra of HFE-7100 and HFC-245fa in air plasma were performed by a TRIO 1000 II instrument (Fisons Instruments, Manchester, U.K.), equipped with a Fisons APCI source. A schematic of this source and of the experimental set up used for the introduction of vaporized samples was given previously [3]. The ion source is kept at near atmospheric pressure by flowing a stream of buffer gas (synthetic air in the present investigation) at $4000-5000 \mathrm{~mL} \cdot \mathrm{min}^{-1}$ introduced through the nebulizer line, a capillary of ca. $2 \mathrm{~mm}$ i.d. The final length (ca. $1 \mathrm{~cm}$ ) of the nebulizer line is wrapped externally with a heating wire, which controls the temperature of the APCI source. Liquid analytes are introduced as vapors which are stripped from a small reservoir by an auxiliary flow of buffer gas. This flow is adjusted to a value (typically $5-50 \mathrm{~mL} \cdot \mathrm{min}^{-1}$ ) such as to obtain a concentration of the analyte in the APCI source within the range 100-1000 $\mathrm{ppm}_{\mathrm{v}}$. Two such lines are available on this instrument and merge into a capillary (i.d. $=0.3$ $\mathrm{mm}$ ) which enters the APCI source running coaxially inside the nebulizer line. Gaseous samples are allowed into the source through one of the two lines after dilution with auxiliary buffer gas flowing through the second line. The two merging flows are independently adjusted by means of two flowmeters, so as to achieve a good intensity of sample signals over the background (typically 5-30 $\mathrm{mL} \cdot \mathrm{min}^{-1}$ ). The concentration of the fluorocarbon samples in air achieved within the APCI source was not quantified.

The needle electrode for corona discharge was kept at $3000 \mathrm{~V}$. Ions leave the source through an orifice, ca. 50 $\mu \mathrm{m}$ in diameter, in the counter electrode (the "sampling cone", held at $0-150 \mathrm{~V}$ relative to ground), cross a region pumped down to ca. $10^{-2}$ Torr $(1$ Torr $=133.3$ $\mathrm{Pa})$ and, through the orifice in a second conical electrode (the "skimmer cone", kept at ground potential), reach the low pressure region hosting the focusing lenses and the quadrupole analyzer. It was shown earlier that collision induced decomposition (CID) experiments can be usefully conducted in the intermediate pressure region between sampling and skimmer cones by the proper adjustment of $\mathrm{V}_{\text {cone, }}$ the difference between their potentials [3]. In our experiments, spectra are recorded at several different values of $\mathrm{V}_{\text {cone }}$ ranging from the lowest possible value (1-5 V) necessary to achieve an acceptable signal to noise ratio up to $150 \mathrm{~V}$. Each experiment also includes, prior to the introduction of the analyte, a preliminary analysis of the "back- 
ground" spectra with only air introduced into the APCI source, again at several different values of $V_{\text {cone }}$ [3]. Before conducting an experiment at $300{ }^{\circ} \mathrm{C}$, the nebulizer was kept at $300-400{ }^{\circ} \mathrm{C}$ for a few of hours and the inlet lines were heated with the help of a heating gun.

Ion/molecule reactions of $\mathrm{H}_{3} \mathrm{O}^{+}\left(\mathrm{H}_{2} \mathrm{O}\right)_{n}(\mathrm{n}=0-2)$, $\mathrm{O}_{2}^{-}, \mathrm{O}_{2}^{-\cdot}\left(\mathrm{H}_{2} \mathrm{O}\right), \mathrm{NO}_{2}^{-}, \mathrm{O}_{3}^{-\cdot}, \mathrm{N}_{2} \mathrm{O}_{2}^{-}, \mathrm{NO}_{3}^{-}$with HFE7100, HFC-245fa and HFC-245ca were performed by a Finnigan TSQ 700 triple quadrupole mass spectrometer (Finnigan MAT, San Jose, CA) equipped with an APCI source. A stream of air was introduced through the sheath gas line with a head pressure of 20 psi. The reagent positive or negative ion, generated by APCI of air, was selected using the first mass analyzer (Q1); the source parameters were optimized to obtain the highest signal to noise ratio for each selected ion. Specifically, for $\mathrm{H}_{3} \mathrm{O}^{+}\left(\mathrm{H}_{2} \mathrm{O}\right)$ and $\mathrm{H}_{3} \mathrm{O}^{+}\left(\mathrm{H}_{2} \mathrm{O}\right)_{2}$, the following experimental conditions were used: source and capillary temperature $50{ }^{\circ} \mathrm{C}$, corona current at 3.7 $\mu \mathrm{A}$, capillary voltage at $5 \mathrm{~V}$, and turbo lenses voltage at $15 \mathrm{~V}$ for $\mathrm{H}_{3} \mathrm{O}^{+}\left(\mathrm{H}_{2} \mathrm{O}\right)_{2}$ and at $30 \mathrm{~V}$ for $\mathrm{H}_{3} \mathrm{O}^{+}\left(\mathrm{H}_{2} \mathrm{O}\right)_{2}$. Linear increase of the turbo lenses voltage is not sufficient to induce complete declustering of $\mathrm{H}_{3} \mathrm{O}^{+}$ ion, requiring for this task a deep change of the operative conditions of the source. The highest yield of $\mathrm{H}_{3} \mathrm{O}^{+}$was obtained by increasing the source and the capillary temperature to $150{ }^{\circ} \mathrm{C}$ and $80{ }^{\circ} \mathrm{C}$, respectively, and the corona current to $6 \mu \mathrm{A}$. The capillary and turbo lenses voltages were then adjusted to maximize the reagent ion signal. In the negative ion mode, the temperature of the source and of the capillary were maintained at $50{ }^{\circ} \mathrm{C}$, while the corona current was the parameter giving the biggest change in the yield of the different ions: a value of $1.5 \mu \mathrm{A}$ was chosen to maximize the intensity of $\mathrm{O}_{2}^{-}$and $\mathrm{O}_{2}^{-\cdot}\left(\mathrm{H}_{2} \mathrm{O}\right)$ ions, while $3.7 \mu \mathrm{A}$ corona current were applied in the case of all the other selected ions $\left(\mathrm{NO}_{2}^{-}, \mathrm{O}_{3}^{-}, \mathrm{N}_{2} \mathrm{O}_{2}^{-}\right.$, $\mathrm{NO}_{3}^{-}$).

The temperature of the manifold was maintained at $70{ }^{\circ} \mathrm{C}$ and neutral reagents were introduced into the collision cell, Q2, via a leak valve (Granville Phillips Co., Boulder, CO). The collision cell pressure was varied between $3.0 \cdot 10^{-4}$ and $2.5 \cdot 10^{-3}$ Torr (uncorrected values) and the optimized collision energy was found to be nominally $0 \mathrm{eV}$. Mass spectra of ion/molecule reaction products were recorded by scanning the second analyzer, Q3.

Ion/molecule reaction of $\mathrm{O}_{2}^{+\cdot}$ with $\mathrm{HFC}-245 \mathrm{fa}$ was performed by a Finnigan TSQ 70 triple quadrupole mass spectrometer (Finnigan MAT, San Jose, CA) equipped with an EI source. The manifold and ion source temperatures were maintained at 150 and $70{ }^{\circ} \mathrm{C}$, respectively. $\mathrm{O}_{2}^{+\cdot}$ was generated by $70 \mathrm{eV}$ electronic ionization (EI) of residual air in the source, and isolated by Q1. HFC-245fa was introduced into Q2 via a leak valve at a pressure of $5.0 \cdot 10^{-4}$, $1.0 \cdot 10^{-3}$, and $1.5 \cdot 10^{-3}$ Torr (uncorrected values) in three independent experiments. Mass spectra of ion/
Table 1. Ionic products of the reactions of selected reagent ions with HFE-7100, HFC-245fa and HFC-245ca (M) observed in APCI-TSQ experiments

\begin{tabular}{llcc}
\hline & \multicolumn{3}{c}{ Reagent ion } \\
\cline { 2 - 4 } M & $\mathrm{H}_{3} \mathrm{O}^{+}$ & $\mathrm{H}_{3} \mathrm{O}^{+}\left(\mathrm{H}_{2} \mathrm{O}\right)$ & $\mathrm{H}_{3} \mathrm{O}^{+}\left(\mathrm{H}_{2} \mathrm{O}\right)_{2}$ \\
\hline \hline $\mathrm{HFE}-7100$ & {$[\mathrm{M}-\mathrm{F}]^{+}$} & - & - \\
HFC-245fa & $\mathrm{H}_{3} \mathrm{O}^{+}(\mathrm{M})$ & $\mathrm{H}_{3} \mathrm{O}^{+}(\mathrm{M})$ (low) & - \\
& $\mathrm{H}_{3} \mathrm{O}^{+}(\mathrm{M})_{2}{ }^{\mathrm{a}}$ & & - \\
& $\mathrm{MH}^{+}$ & & \\
$\mathrm{HFC}-245 \mathrm{ca}$ & $\mathrm{H}_{3} \mathrm{O}^{+}(\mathrm{M})^{2}$ & - & \\
& $\mathrm{H}_{3} \mathrm{O}^{+}(\mathrm{M})_{2}{ }^{\mathrm{a}}$ & & \\
& & \\
\end{tabular}

${ }^{a}$ Observed only at high pressure.

molecule reaction products were recorded by scanning Q3.

All experiments were replicated at least twice, yielding in all cases reproducible results.

\section{Results and Discussion}

Ionization of organic compounds within the APCI source is due to ion/molecule reactions with ions of the air plasma generated by corona discharge. These reactant ions are readily observed when pure air is introduced into the source and produce what we call the 'background' spectra. 'Background' spectra are routinely acquired and analyzed prior to each experiment under the specific experimental conditions of temperature and humidity that will be used in the experiment. The "background" spectra obtained in the present study under various different experimental conditions are consistent with earlier ones, which were described in $^{\circ}$ detail $^{\circ}$ in $^{\circ}$ previous ${ }^{\circ}$ publications ${ }^{\circ}\left[3,{ }^{\circ} 6\right] .{ }^{\circ}$ Briefly, ${ }^{\circ}$ major "background" positive ions are $\mathrm{H}_{3} \mathrm{O}^{+}\left(\mathrm{H}_{2} \mathrm{O}\right)_{n}$, with $\mathrm{NO}^{+}\left(\mathrm{H}_{2} \mathrm{O}\right)_{\mathrm{n}}$ being also observed although in lower abundance. Depending on the APCI source temperature and on the amount of residual humidity in the apparatus, more- or less-heavily solvated ions prevail at low values of $\mathrm{V}_{\text {cone: }}$ typically, in dry air at $30^{\circ} \mathrm{C}$, complexes with $\mathrm{n}=1-4$ are observed, the most abundant usually being $\mathrm{H}_{3} \mathrm{O}^{+}\left(\mathrm{H}_{2} \mathrm{O}\right)_{3}$, while at high temperatures $\left(300^{\circ} \mathrm{C}\right)$ smaller clusters prevail. In addition, minor amounts of $\mathrm{O}_{2}^{+\cdot}\left(\mathrm{H}_{2} \mathrm{O}\right)$ and $\mathrm{O}_{2}^{+\cdot}\left(\mathrm{H}_{2} \mathrm{O}\right)_{2}$ are also detected at $300{ }^{\circ} \mathrm{C}$. As $\mathrm{V}_{\text {cone }}$ is gradually increased, collision induced dissociation produces smaller clusters and eventually the bare $\mathrm{H}_{3} \mathrm{O}^{+}$and $\mathrm{NO}^{+}$ions. Finally, at yet higher values of $\mathrm{V}_{\text {cone }}(\geq 90-100 \mathrm{~V})$ only three signals are detected, at $m / z 29,32$, and 33, which are attributed to $\mathrm{N}_{2} \mathrm{H}^{+}, \mathrm{O}_{2}^{+\cdot}$, and $\mathrm{O}_{2} \mathrm{H}^{+}$, respectively, formed ${ }^{\circ}{ }^{\circ}{ }^{\circ}$ endothermic ${ }^{\circ}$ ion $/$ molecule $^{\circ}$ reactions ${ }^{\circ}[6]$.

Hydrates $\mathrm{O}_{2}^{-\cdot}\left(\mathrm{H}_{2} \mathrm{O}\right)_{n}$ and $\mathrm{O}_{3}^{-\cdot}\left(\mathrm{H}_{2} \mathrm{O}\right)_{n}$ are the major "background" negative ions, with $\mathrm{n}$ ranging typically between 0 and 3 depending, as for the positive cluster ions, on the temperature and on the amount of residual humidity within the APCI source. In addition, the 


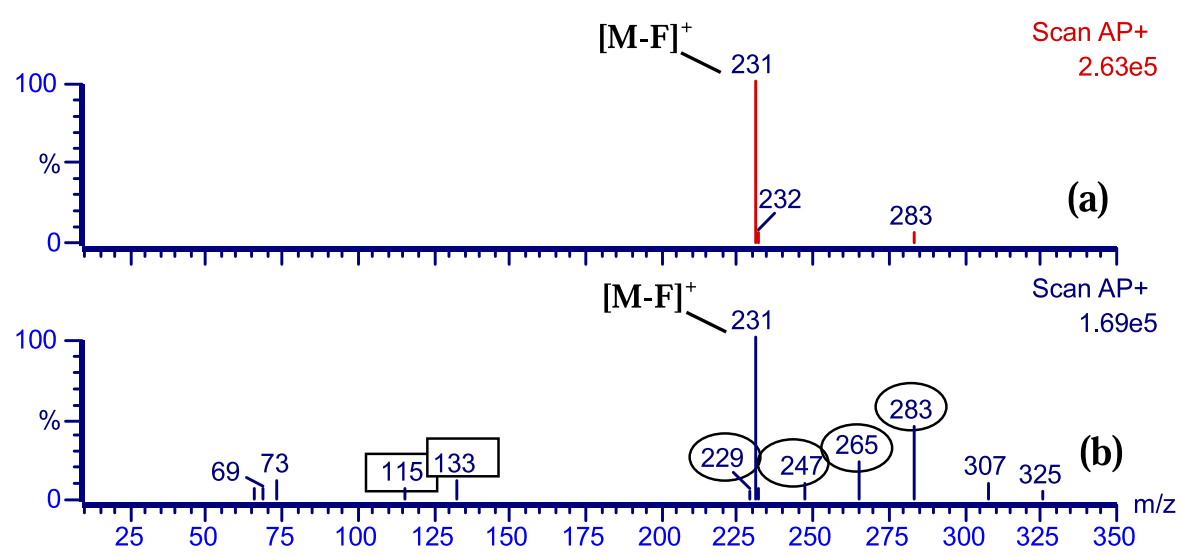

Figure 1. Positive APCI spectra of HFE-7100 in synthetic air recorded at $\mathrm{V}_{\text {cone }}=1 \mathrm{~V}$ and (a) $300{ }^{\circ} \mathrm{C}$ (b) $30^{\circ} \mathrm{C}$. Enclosed in rectangles: ion/molecule complexes of $\mathrm{C}_{2} \mathrm{FH}_{4} \mathrm{O}_{2}^{+}(\mathrm{m} / \mathrm{z} 79)$ with water molecules. Enclosed in circles: ion/molecule complexes of $\mathrm{C}_{5} \mathrm{~F}_{7} \mathrm{H}_{4} \mathrm{O}_{2}^{+}(\mathrm{m} / \mathrm{z} 229)$ with water molecules.

$\mathrm{O}_{2}^{-\cdot}\left(\mathrm{O}_{2}\right)$ species is also detected, more prominently at $300{ }^{\circ} \mathrm{C}$. As $\mathrm{V}_{\text {cone }}$ is gradually increased, the clusters decrease in size by releasing water molecules, and eventually the bare anions are collected. At yet higher values $\left(\mathrm{V}_{\text {cone }} \geq 70-80 \mathrm{~V}\right)$, a signal at $m / z 16$ is observed which is attributed to $\mathrm{O}^{-}$. Depending on the source conditions, minor signals are also seen in the background spectra at $m / z 46,60$, and 62 , which are attributed to $\mathrm{NO}_{2}^{-}, \mathrm{N}_{2} \mathrm{O}_{2}^{-}$, and $\mathrm{NO}_{3}^{-}$, respectively. Such anions are reasonably related to corona-induced reactions in air which are known to produce $\mathrm{NO}_{\mathrm{x}}$. Specifically, the attribution of the signal observed at $\mathrm{m} / \mathrm{z} 60$ in APCI experiments to $\mathrm{N}_{2} \mathrm{O}_{2}^{--}$rather than $\mathrm{CO}_{3}^{-\cdot}$ was briefly $^{\circ}$ discussed $^{\circ}{ }^{\circ}{ }^{\circ} a^{\circ}$ earlier $^{\circ}$ publication ${ }^{\circ}[3]$.

The results are organized in two major sections, one for positive and the other for negative ions. Within each section, the behavior in air plasma of the two VOCs is described and discussed with reference to the results of specific ion/molecule reactions performed with the APCI-TSQ instrumentation. For convenience, at the beginning of each section a table is included which summarizes the main results obtained in the APCI-TSQ selected ion/molecule reaction studies with the compounds investigated.

\section{Positive Ions}

The ionic products observed in the reactions performed with $^{\circ}$ APCI-triple ${ }^{\circ}$ quadrupole $^{\circ}$ are $^{\circ}$ summarized $^{\circ}$ in $^{\circ} \mathrm{Ta}^{-}$ ble ${ }^{\circ}$.

\section{HFE-7100 (Nonafluorobutyl Methyl Ether)}

The positive APCI spectrum of HFE-7100 (M) at low values of $\mathrm{V}_{\text {cone }}$ both at $300{ }^{\circ} \mathrm{C}$ and $30^{\circ} \mathrm{C}$ is dominated by a signal at $\mathrm{m} / \mathrm{z} 231$ attributable to $\left[\mathrm{M}-\mathrm{F}^{+}\right.$species (Figure $\left.^{\circ} 1\right)^{\circ}{ }^{\circ} \mathrm{It}^{\circ}$ is ${ }^{\circ}$ evident $^{\circ}$ from $^{\circ}$ Figure $^{\circ} 1 \mathrm{~b}^{\circ}$ that $^{\circ}$ several additional ions are present at $30^{\circ} \mathrm{C}$ : as discussed in detail later, these are water clusters of two product ions at $m / z 229$ and 79, which are attributed to the species $\mathrm{C}_{5} \mathrm{~F}_{7} \mathrm{H}_{4} \mathrm{O}_{2}^{+}$and $\mathrm{C}_{2} \mathrm{FH}_{4} \mathrm{O}_{2}^{+}$, respectively.

The proton affinity and the ionization energy of HFE-7100 are not available to support any hypothesis on the ionization of this isomeric pair of compounds under APCI conditions: important clues came, however, from the study of the reaction with $\mathrm{H}_{3} \mathrm{O}^{+}$in the collision cell of the triple quadrupole. Regardless of the pressure inside the cell, the only observed product was invariably the $\left[\mathrm{M}-\mathrm{F}^{+}\right.$species, likely formed via proton transfer and elimination of a molecule of hydrogen fluoride, as exemplified in eq 1.

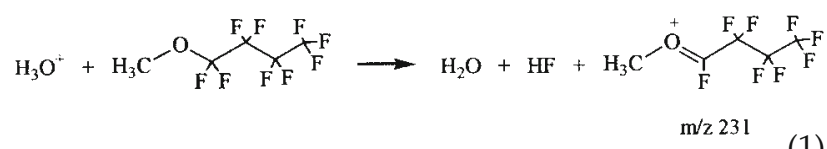

It is reasonable to assume that the same process is taking place in the air plasma at atmospheric pressure within the APCI source, where $\mathrm{H}_{3} \mathrm{O}^{+}$and its hydrates are the major "background" ions.

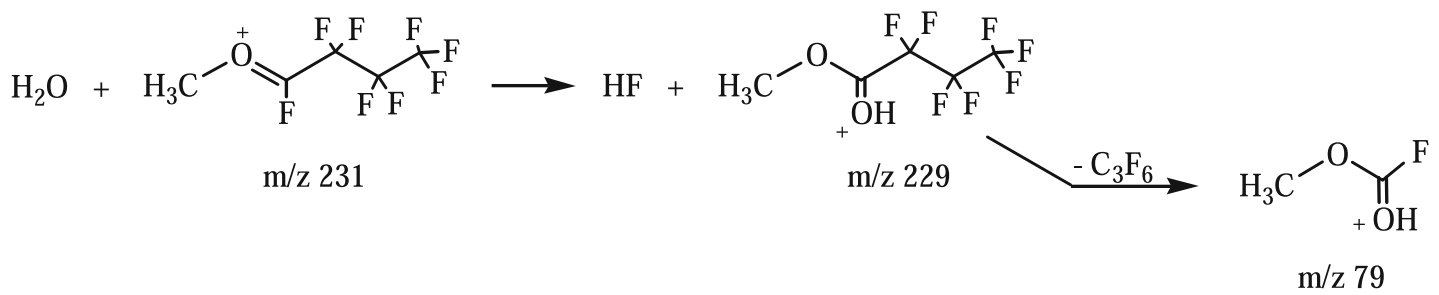

Scheme 1. Proposed route for formation of $m / z 229$ and 79 in APCI-MS of HFE-7100 in humid air. 

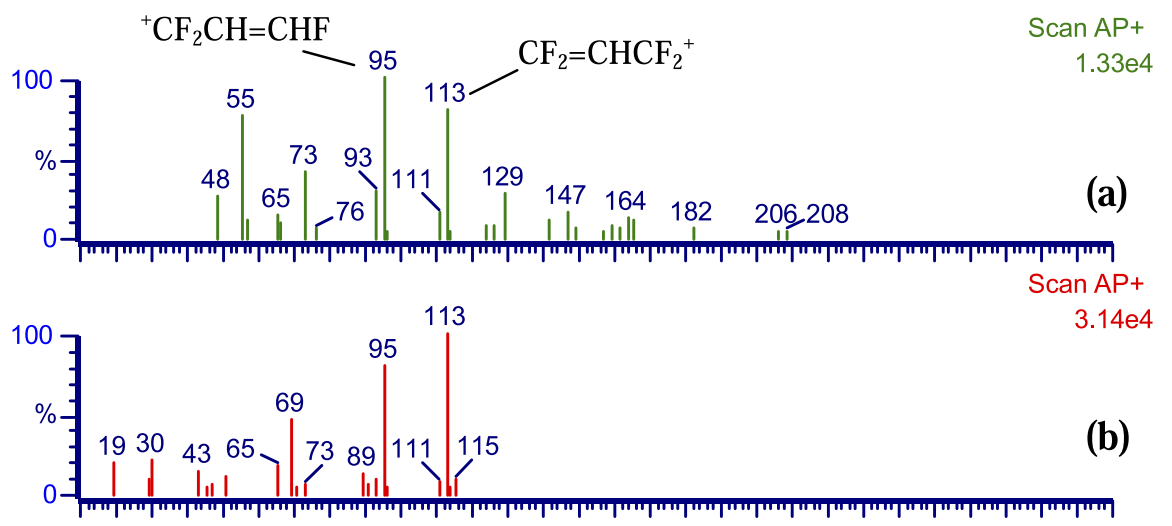

$3.14 \mathrm{e} 4$

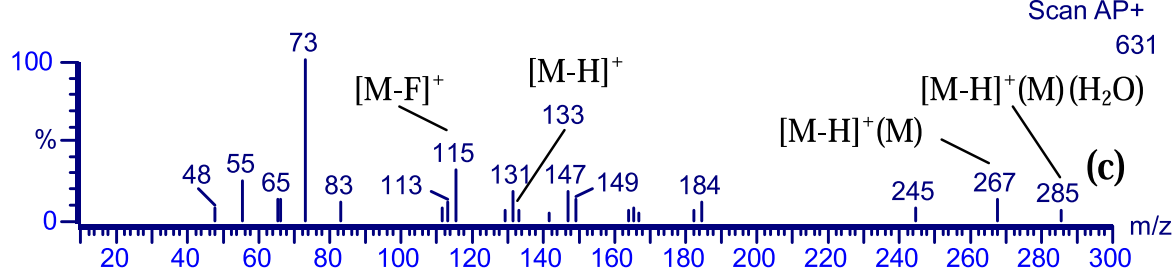

Figure 2. Positive APCI spectra of HFC-245fa in synthetic air recorded at (a) $\mathrm{V}_{\text {cone }}=1 \mathrm{~V}$ and $300^{\circ} \mathrm{C}$, (b) $\mathrm{V}_{\text {cone }}=110 \mathrm{~V}$ and $300^{\circ} \mathrm{C}$, and (c) $\mathrm{V}_{\text {cone }}=1 \mathrm{~V}$ and $30^{\circ} \mathrm{C}$.

As $\mathrm{V}_{\text {cone }}$ is increased, $\left[\mathrm{M}-\mathrm{F}^{+}\right.$ions dissociate to $\mathrm{CH}_{3} \mathrm{OCF}_{2}^{+}(m / z \quad 81), \quad \mathrm{CF}_{3} \mathrm{CF}_{2} \mathrm{CF}_{2}^{+}(m / z \quad 169)$, and $\mathrm{O}=\mathrm{CFCF}_{2} \mathrm{CF}_{2} \mathrm{CF}_{2}^{+}(\mathrm{m} / \mathrm{z} 197)$, and at yet higher $\mathrm{V}_{\text {cone, }}$ also to $\mathrm{CF}_{3} \mathrm{CF}_{2}^{+}(\mathrm{m} / \mathrm{z} 119)$ and $\mathrm{CF}_{3}^{+}(\mathrm{m} / \mathrm{z}$ 69). This data is not shown here. When a greater amount of water is present inside the APCI source, as is typical at $30^{\circ} \mathrm{C}$, a second process is observed, leading to the formation of the ions at $m / z 229$ and $m / z$ 79. Our hypothesis, shown in Scheme 1, is that $[\mathrm{M}-\mathrm{F}]^{+}$, formed in the reaction of $\mathrm{M}$ with $\mathrm{H}_{3} \mathrm{O}^{+}$(eq 1), undergoes water addition and $\mathrm{HF}$ elimination to form the product $\mathrm{C}_{5} \mathrm{~F}_{7} \mathrm{H}_{4} \mathrm{O}_{2}^{+}$at $\mathrm{m} / \mathrm{z} 229$ : this protonated ester species can dissociate via elimination of $\mathrm{C}_{3} \mathrm{~F}_{6}$ to produce $\mathrm{C}_{2} \mathrm{FH}_{4} \mathrm{O}_{2}^{+}$at $m / z 79$.

Support for this proposal came from experiments with $\mathrm{D}_{2} \mathrm{O}$ which resulted in the expected deuterium incorporation in the reaction product ion, causing a shift of the signal from $m / z 229$ to $m / z 230$. Furthermore, CID experiments conducted in the APCI source by increasing $\mathrm{V}_{\text {cone }}$ produced fragment ions at $\mathrm{m} / \mathrm{z} 209$ and 59 , which can be ascribed to dissociation via HF loss of the species at $m / z 229$ and 79 , respectively.

\section{HFC-245fa (1,1,1,3,3-Pentafluoropropane)}

The positive APCI spectrum of HFC-245fa (M) obtained at $300{ }^{\circ} \mathrm{C}$ and at low values of $\mathrm{V}_{\text {cone }}{ }^{\text {is }}{ }^{\circ}$ shown ${ }^{\circ}$ in ${ }^{\circ}$ Figure

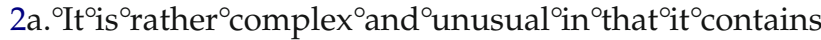
no evidence for the molecular ion $\left(\mathrm{M}^{+}, \mathrm{m} / z\right.$ 134) or the protonated species $[\mathrm{MH}]^{+}$or any $[\mathrm{M}-\mathrm{F}]^{+}(\mathrm{m} / \mathrm{z} 115)$ product ion: instead, several other signals are detected, the major ones of which are found at $m / z 95$ and $m / z 113$. The attribution of these signals to specific ionic products and a rationale for their formation, not a trivial task, were achieved mainly through selected ion/molecule reaction experiments performed with the APCITSQ.

The signal at $m / z 95$ can only be attributed to a $\mathrm{C}_{3} \mathrm{~F}_{3} \mathrm{H}_{2}^{+}$product ion. By analogy to what was found with HFE-7100 (see eq 1 above), it was reasonable to expect that HFC-245fa should react with $\mathrm{H}_{3} \mathrm{O}^{+}$to give $[\mathrm{M}-\mathrm{F}]^{+}$(not observed), which dissociates to $\mathrm{C}_{3} \mathrm{~F}_{3} \mathrm{H}_{2}^{+}$ via $\mathrm{HF}$ elimination, as illustrated in Scheme 2 . It will be shown, however, that this reaction scheme is not supported by the results of APCI-TSQ experiments described below.

As for the peak at $m / z 113$, the other major signal in the ${ }^{\circ} \mathrm{APCI}{ }^{\circ}$ spectrum ${ }^{\circ}$ of $\mathrm{HFC}-245 \mathrm{fa}^{\circ}$ (Figure $\left.2 \mathrm{a}\right)$, it $^{\circ}$ could $\mathrm{be}$ assigned to any of three different species, $\mathrm{C}_{3} \mathrm{~F}_{3} \mathrm{H}_{2}\left(\mathrm{H}_{2} \mathrm{O}\right)^{+}, \mathrm{C}_{3} \mathrm{~F}_{3} \mathrm{H}_{4} \mathrm{O}^{+}$, and $\mathrm{C}_{3} \mathrm{~F}_{4} \mathrm{H}^{+}$. The first option, i.e., that $m / z 113$ is the hydrate of $m / z$ 95, seemed very likely since hydrates are usually observed in APCI experiments. This hypothesis, however, is inconsistent

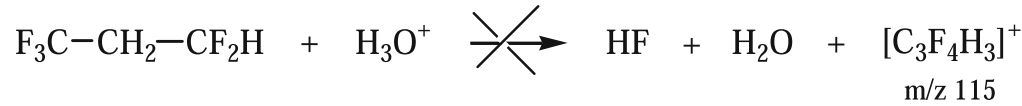

$$
\begin{aligned}
& \mathrm{HF}+\mathrm{C}_{3} \mathrm{~F}_{3} \mathrm{H}_{2}^{+} \\
& \mathrm{m} / \mathrm{z} 95
\end{aligned}
$$

Scheme 2. Possible but rejected route for formation of $\mathrm{C}_{3} \mathrm{~F}_{3} \mathrm{H}_{2}^{+}$in APCI-MS of HFC-245fa. 


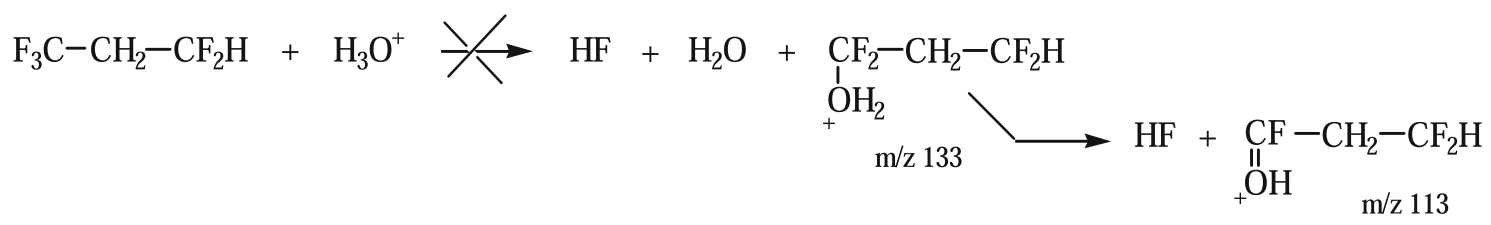

Scheme 3. Possible but rejected route for formation of $\mathrm{C}_{3} \mathrm{~F}_{3} \mathrm{H}_{4} \mathrm{O}^{+}$in APCI-MS of HFC-245fa.

with the high persistence of the signal at $\mathrm{m} / \mathrm{z} 113$ when $\mathrm{V}_{\text {cone }}$ is $^{\circ}$ increased $^{\circ}\left(\right.$ Figure $^{\circ} 2 \mathrm{~b}$ ), ${ }^{\circ}$ typical ${ }^{\circ}$ of ${ }^{\circ} \mathrm{a}^{\circ}$ covalent species and not of an ion/molecule complex.

The second possibility, i.e., that $\mathrm{m} / \mathrm{z} 113$ is the oxygenated product $\mathrm{C}_{3} \mathrm{~F}_{3} \mathrm{H}_{4} \mathrm{O}^{+}$, also seemed quite reasonable considering a reaction of HFC-245fa with $\mathrm{H}_{3} \mathrm{O}^{+}$(Scheme 3 ) in analogy to the reaction observed with 1,1-difluoroethane ${ }^{\circ}$ under $^{\circ}$ similar $^{\circ}$ experimental ${ }^{\circ}$ conditions $^{\circ}[6]$.

However, when deuterated water was introduced into the APCI source, the expected mass shift from $\mathrm{m} / \mathrm{z}$ 113 to $\mathrm{m} / \mathrm{z} 114$ for the product ion of the reaction of HFC-245fa with $\mathrm{D}_{3} \mathrm{O}^{+}$according to Scheme 3 was not observed. Indeed, only a minor signal appeared in the spectrum at $\mathrm{m} / \mathrm{z} 114$, the major signal remaining at $\mathrm{m} / \mathrm{z}$ 113. This result is in contrast with the proposal of Scheme 3 but is, instead, consistent with the third possible composition mentioned above for $\mathrm{m} / \mathrm{z} 113$, namely, $\mathrm{C}_{3} \mathrm{~F}_{4} \mathrm{H}^{+}$; such an ion should undergo limited deuterium/proton exchange, as observed by Heck et al. [9] ${ }^{\circ}$ for $^{\circ}$ analogous ${ }^{\circ}$ species.

Conclusive indications as to the composition and origin of the major ionization products of HFC-245fa in air plasma, namely the ions at $\mathrm{m} / \mathrm{z} 95$ and $\mathrm{m} / \mathrm{z} 113$, came from selected ion/molecule APCI-TSQ experiments. It was found indeed that reaction of HFC-245fa with $\mathrm{H}_{3} \mathrm{O}^{+}$gives only two products, the complex $\mathrm{H}_{3} \mathrm{O}^{+} \cdot \mathrm{M}$ as the major product and, to a lesser extent, the protonated species ${ }^{\circ} \mathrm{MH}^{+}{ }^{\circ}\left(\right.$ Table $\left.^{\circ} 1\right) .{ }^{\circ} \mathrm{A}^{\circ}$ Similar $^{\circ}$ behavior ${ }^{\circ}$ is $^{\circ}$ observed for the isomeric pentafluoropropane studied, HFC$245 \mathrm{ca}$. Thus, the reactions shown in both Scheme 2 and Scheme 3 were ruled out, and other ions were probed as possible precursors of the $\mathrm{m} / \mathrm{z} 95$ and 113 products. Notably, $\mathrm{O}_{2}^{+}$, a major primary ion in air plasma, was found to react with HFC-245fa to give $\mathrm{C}_{3} \mathrm{~F}_{4} \mathrm{H}_{3}^{+}(\mathrm{m} / \mathrm{z}$ 115) and $\mathrm{C}_{3} \mathrm{~F}_{5} \mathrm{H}_{2}^{+}(\mathrm{m} / \mathrm{z} 133)$ via fluoride and hydride transfer, respectively ${ }^{\circ}$ (Figure $\left.{ }^{\circ} 3\right) .^{\circ}$ These $^{\circ}$ two $^{\circ}$ products $^{\circ}$ are ${ }^{\circ}$ likely precursors of the ions at $\mathrm{m} / \mathrm{z} 95$ and 113, observed as major products of the ionization of HFC-245fa under APCI conditions. Thus, the ion $\mathrm{C}_{3} \mathrm{~F}_{4} \mathrm{H}^{+}(\mathrm{m} / z$ 113) can be ascribed to dissociation, via HF loss, of $\mathrm{C}_{3} \mathrm{~F}_{5} \mathrm{H}_{2}^{+}$, the product of hydride transfer. Analogously, $\mathrm{C}_{3} \mathrm{~F}_{3} \mathrm{H}_{2}^{+}(\mathrm{m} / \mathrm{z}$ 95) can originate via $\mathrm{HF}$ loss from $\mathrm{C}_{3} \mathrm{~F}_{4} \mathrm{H}_{3}^{+}$, the product of fluoride transfer (Scheme 4).

Elimination of $\mathrm{HF}$ is a commonly observed process for ${ }^{\circ}$ fluorinated ${ }^{\circ}$ organic $^{\circ}$ cations $^{\circ}[10] . .^{\circ} \mathrm{A}^{\circ}$ relevant ${ }^{\circ}$ example is ${ }^{\circ}$ reported by ${ }^{\circ}$ guyen $^{\circ} \mathrm{et}^{\circ} \mathrm{al} . .^{\circ}[11]$, ${ }^{\circ}$ who ${ }^{\circ}$ observed ${ }^{\circ} \mathrm{HF}$ \%oss from $\mathrm{C}_{3} \mathrm{~F}_{4} \mathrm{H}_{3}^{+}(\mathrm{m} / \mathrm{z} 115)$, a structural isomer of the species shown in Scheme 4, formed via a methathesis reaction in the chemical ionization of acetone with $\mathrm{CF}_{4}$.

Another important product of the reaction of $\mathrm{O}_{2}^{+}$ with HFC-245fa is the ionized olefin $\left[\mathrm{CH}_{2}=\mathrm{CF}_{2}\right]^{+\cdot}(\mathrm{m} / \mathrm{z}$ 64), which could form via hydrogen abstraction by $\mathrm{O}_{2}^{+}$. and elimination of $\mathrm{CF}_{3}$ as shown in Scheme 5.

In the APCI spectra obtained at low temperature

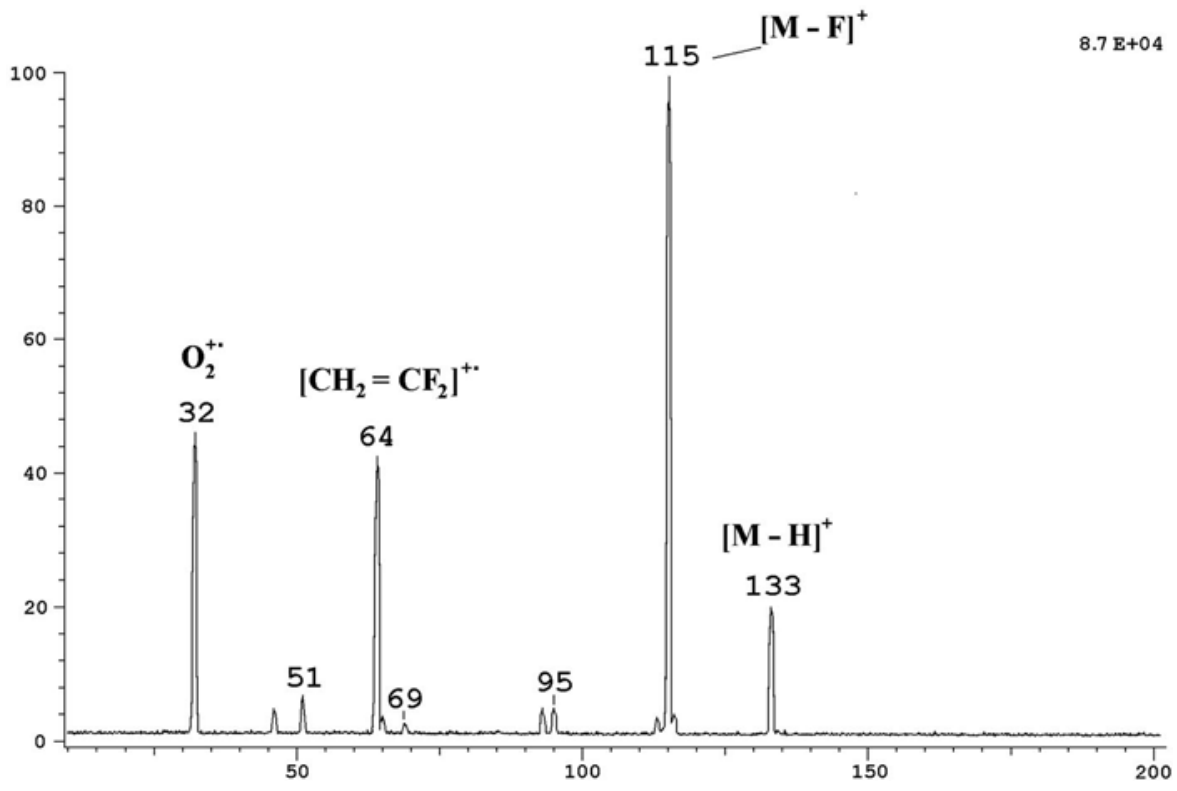

Figure 3. APCI-TSQ mass spectrum of the products of the reaction of $\mathrm{O}_{2}^{+}$with HFC-245fa at a nominal pressure of about $1.5 \cdot 10^{-3}$ Torr. 


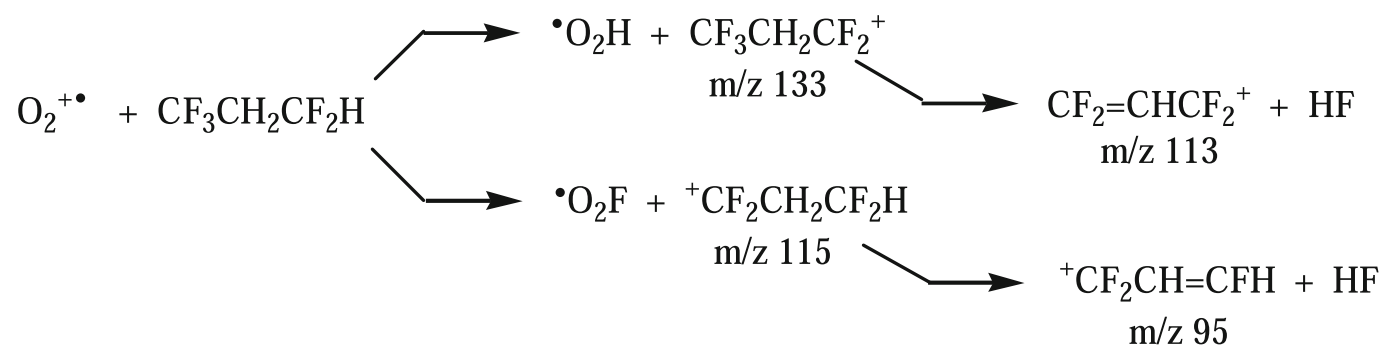

Scheme 4. Proposed route for formation of the ions at $m / z$ 95, 113, 115, and 133 in APCI-MS of HFC-245fa.

$\left(30^{\circ} \mathrm{C}\right)$, the signals due to HFC-245fa remained of low intensity with respect to those of the background also when the hydrofluorocarbon was present in high concentration ${ }^{\circ}$ inside ${ }^{\circ}$ the ${ }^{\circ}$ source $^{\circ}$ (Figure $\left.{ }^{\circ} 2 \mathrm{c}\right) .{ }^{\circ}$ Interestingly, ${ }^{\circ}$ under these conditions the products of fluoride transfer $\left(\mathrm{C}_{3} \mathrm{~F}_{4} \mathrm{H}_{3}^{+}\right.$, $m / z$ 115) and hydride transfer $\left(\mathrm{C}_{3} \mathrm{~F}_{5} \mathrm{H}_{2}^{+}, m / z 133\right)$, which are not detected at $300{ }^{\circ} \mathrm{C}$, could be readily observed as free ions and/or as ion/molecule complexes. Thus, $\mathrm{C}_{3} \mathrm{~F}_{5} \mathrm{H}_{2}^{+}$is mainly detected as the ion/molecule complexes $\left(\mathrm{C}_{3} \mathrm{~F}_{5} \mathrm{H}_{2}^{+}\right) \mathrm{M}$ at $\mathrm{m} / \mathrm{z} 267$ and $\left(\mathrm{C}_{3} \mathrm{~F}_{5} \mathrm{H}_{2}^{+}\right)(\mathrm{M})\left(\mathrm{H}_{2} \mathrm{O}\right)$ at $\mathrm{m} / \mathrm{z} 285$. The observation of the products of fluoride transfer $\left(\mathrm{C}_{3} \mathrm{~F}_{4} \mathrm{H}_{3}^{+}, \mathrm{m} / \mathrm{z} 115\right)$ and hydride transfer $\left(\mathrm{C}_{3} \mathrm{~F}_{5} \mathrm{H}_{2}^{+}, \mathrm{m} / \mathrm{z} 133\right)$ provides strong support for the proposal of their intermediacy in the ionization/dissociation routes sketched in Scheme 4. The different degrees to which the processes described in Scheme 4 are observed at $30^{\circ} \mathrm{C}$ and $300{ }^{\circ} \mathrm{C}$ are $^{\circ}$ ascribed $^{\circ}$ to $^{\circ}$ the ${ }^{\circ}$ higher $^{\circ}$ internal ${ }^{\circ}$ energy $^{\circ}$ of $^{\circ}$ the ${ }^{\circ}$ ions ${ }^{\circ}$ at $300{ }^{\circ} \mathrm{C}$.

Other significant signals in the APCI spectrum of HFC-245fa at $300{ }^{\circ} \mathrm{C}$ are detected at $\mathrm{m} / \mathrm{z} 93,111$, and 129 (Figure 2a). ${ }^{\circ} \mathrm{A}^{\circ}$ first ${ }^{\circ}$ hypothesis ${ }^{\circ}$ that ${ }^{\circ}$ they ${ }^{\circ}{ }^{\circ}$ could be $^{\circ}$ due ${ }^{\circ}$ to species $\mathrm{C}_{3} \mathrm{~F}_{3}^{+}\left(\mathrm{H}_{2} \mathrm{O}\right)_{\mathrm{n}}(\mathrm{n}=0-2)$ had to be rejected, based on experiments performed with $\mathrm{D}_{2} \mathrm{O}$ at different values of $\mathrm{V}_{\text {cone }}$. These experiments, not shown, indicated that the ion at $\mathrm{m} / \mathrm{z} 129$ contains only two exchangeable protons and can be viewed as a monohydrated species, i.e., the hydrate complex of the ion at $m / z 111$. The latter, however, has no exchangeable protons and therefore cannot be a water cluster of the ion at $m / z 93$.

Further experiments were performed by varying the amount ${ }^{\circ}{ }^{\circ}{ }^{\circ}{ }^{\text {water }}{ }^{\circ}{ }^{\circ}{ }^{\circ}$ the ${ }^{\circ} \mathrm{APCI}^{\circ}$ source. ${ }^{\circ}$ Figure ${ }^{\circ} 4^{\circ}$ reports ${ }^{\circ} \mathrm{a}$ few examples of spectra obtained with increasing amounts of water while maintaining constant both $\mathrm{V}_{\text {cone }}$ and the amount of HFC-245fa admitted into the APCI source. It is easily seen that as the amount of water is increased, the abundance of ${ }^{+} \mathrm{CF}_{2}-\mathrm{CH}=\mathrm{CHF}$ at $m / z 95$ and $\mathrm{CF}_{2}-\mathrm{CH}=\mathrm{CF}_{2}^{+}$at $m / z 113$ decreases suggesting that both ions are quenched by water. Such decay is matched by complex changes in the observed ion population which are due to the combination of different reactions involving water as the neutral reagent: $\mathrm{C}-\mathrm{O}$ covalent bond formation via water addition and HF eliminations and clustering of the products of such reactions. A rationale for the processes occurring within the plasma in humid air is offered in Scheme 6 which is based on and consistent with all experimental results obtained in experiments conducted with $\mathrm{D}_{2} \mathrm{O}$ and in $\mathrm{CID}$ experiments performed by increasing $\mathrm{V}_{\text {cone }}$.

As the amount of water inside the source is increased, the abundance of the ions ${ }^{+} \mathrm{CF}_{2}-\mathrm{CH}=\mathrm{CHF}$ and $\mathrm{CF}_{2}-\mathrm{CH}=\mathrm{CF}_{2}^{+}(\mathrm{m} / z \mathrm{~g} 5$ and 113) decreases, while that of their products of $\mathrm{H}_{2} \mathrm{O}$ addition and $\mathrm{HF}$ elimination increases $(\mathrm{m} / \mathrm{z} 93$ and 111 , labeled $\mathbf{a}$ and $\mathbf{b}$, respectively). Note that these products are detected mainly as hydrates, $\mathbf{a}\left(\mathrm{H}_{2} \mathrm{O}\right)_{\mathrm{n}^{\circ}}$ and $^{\circ} \mathbf{b}\left(\mathrm{H}_{2} \mathrm{O}\right)_{\mathrm{m}^{\circ}}\left(\mathrm{n},{ }^{\circ} \mathrm{m}^{\circ}={ }^{\circ} 1-3\right)^{\circ}$ (Figure $\left.{ }^{\circ} 4\right)$. Note also the complication that the hydrates $\mathbf{a}\left(\mathrm{H}_{2} \mathrm{O}\right)_{\mathrm{n}}(\mathrm{n}$ $=1-3)$ and $\mathbf{b}\left(\mathrm{H}_{2} \mathrm{O}\right)_{\mathrm{m}}(\mathrm{m}=0-2)$ are isobaric $(\mathrm{m} / \mathrm{z} 111$, $129,147)$ since $\mathbf{a}$ and $\mathbf{b}$ differ by 18 mass units because of the substitution of a hydrogen by a fluorine.

A second HF elimination step is then observed from ions $\mathbf{a}$ and $\mathbf{b}$ forming, respectively, product ions $\mathbf{a}^{\prime}(\mathrm{m} / \mathrm{z}$ 73) $)^{\circ}$ and $^{\circ} \mathbf{b}^{\prime}{ }^{\circ}\left(\mathrm{m} / \mathrm{z}\right.$ 91). . These ions ${ }^{\circ}$ are ${ }^{\circ}$ also ${ }^{\circ}$ detected ${ }^{\circ}$ mainly as water complexes, $\mathbf{a}^{\prime}\left(\mathrm{H}_{2} \mathrm{O}\right)_{\mathrm{n}^{\circ}}$ and $^{\circ} \mathbf{b}^{\prime}\left(\mathrm{H}_{2} \mathrm{O}\right)_{\mathrm{m}^{\circ}}$ (Figure 4 ). Moreover the complexes $\mathbf{a}^{\prime}\left(\mathrm{H}_{2} \mathrm{O}\right)_{\mathrm{n}}(\mathrm{n}=1-3)$ are isobaric with $\mathbf{b}^{\prime}\left(\mathrm{H}_{2} \mathrm{O}\right)_{\mathrm{m}}(\mathrm{m}=0-2)(\mathrm{m} / \mathrm{z} 91,109,127)$. Reciprocal interferences are however eliminated when water is lost by increasing $\mathrm{V}_{\text {cone }}$ and the dissociation behavior of the bare ions, at $\mathrm{m} / \mathrm{z} 73$ and 91, can be observed. Both species undergo characteristic $\mathrm{CO}$ loss which provides further support for their assignments. Another interference is due to the superposition of the signal attributable to $\mathbf{a}^{\prime}$ with that attributable to the background ion

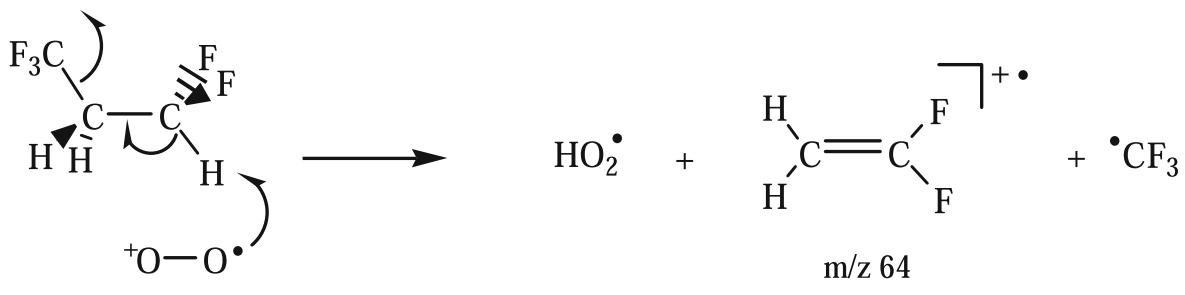

Scheme 5. Proposed mechanism for formation of $m / z 64$ in the reaction of HFC-245fa with $\mathrm{O}_{2}^{+ \text {. }}$ 

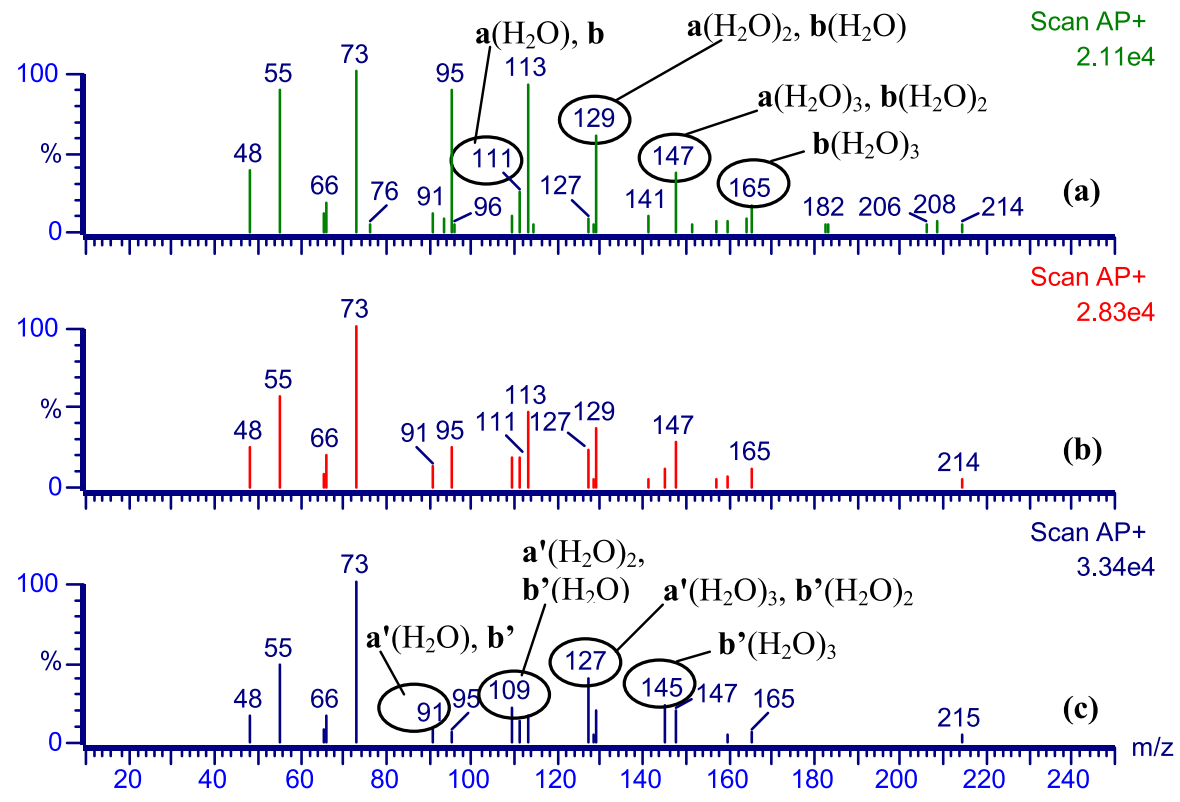

Figure 4. Positive APCI spectra of HFC-245fa in synthetic air recorded at $\mathrm{V}_{\text {cone }}=1 \mathrm{~V}$ and $300{ }^{\circ} \mathrm{C}$ with the addtion of $\mathrm{H}_{2} \mathrm{O}$ at a flow of (a) $10 \mathrm{~mL} \cdot \mathrm{min}^{-1}$, (b) $20 \mathrm{~mL} \cdot \mathrm{min}^{-1}$, and (c) $30 \mathrm{~mL} \cdot \mathrm{min}^{-1}$.

$\mathrm{H}_{3} \mathrm{O}^{+}\left(\mathrm{H}_{2} \mathrm{O}\right)_{3}$. It should be noted that the major signal at $\mathrm{m} / \mathrm{z} 73$, observed under low potential conditions both at $30^{\circ}$ and $300^{\circ} \mathrm{C}$, is mainly due to the complex $\mathrm{H}_{3} \mathrm{O}^{+}\left(\mathrm{H}_{2} \mathrm{O}\right)_{3}$, particularly abundant when water is added into the source.

Finally, both at $300^{\circ}$ and at $30^{\circ} \mathrm{C}$ the APCI spectra contain signals at $\mathrm{m} / \mathrm{z} 164$ and 182 which are due to complexes $\mathrm{NO}^{+}(\mathrm{M})$ and $\mathrm{NO}^{+}\left(\mathrm{H}_{2} \mathrm{O}\right)(\mathrm{M})$, respectively.

\section{Negative Ions}

The ionic products observed in the reactions performed with ${ }^{\circ}$ APCI-triple ${ }^{\circ}$ quadrupole ${ }^{\circ}{ }^{\circ}{ }^{\circ}$ summarized $^{\circ}{ }^{\circ}{ }^{\circ}$ Table $^{\circ}$.

\section{HFE-7100 (Nonafluorobutyl Methyl Ether)}

In the negative APCI spectra of HFE-7100 recorded at 300 and $30^{\circ} \mathrm{C}$, the only signal detected at low values of

$$
\begin{aligned}
& { }^{+} \mathrm{CF}_{2}-\mathrm{CH}=\mathrm{CFH}+\mathrm{H}_{2} \mathrm{O} \longrightarrow \mathrm{HO}=\mathrm{+}=\mathrm{CF}-\mathrm{CH}=\mathrm{CFH}+\mathrm{HF} \\
& \mathrm{m} / \mathrm{z} 95 \\
& \text { a } \mathrm{m} / \mathrm{z} 93 \\
& \mathrm{O}=\stackrel{+}{\mathrm{C}}-\mathrm{CH}=\mathrm{CFH}+\mathrm{HF} \\
& a^{\prime} \mathrm{m} / \mathrm{z} 73 \\
& \stackrel{\mathrm{CID}}{\longrightarrow}+{ }^{+} \mathrm{CH}=\mathrm{CFH}+\mathrm{CO} \\
& \mathrm{m} / \mathrm{z} 45
\end{aligned}
$$

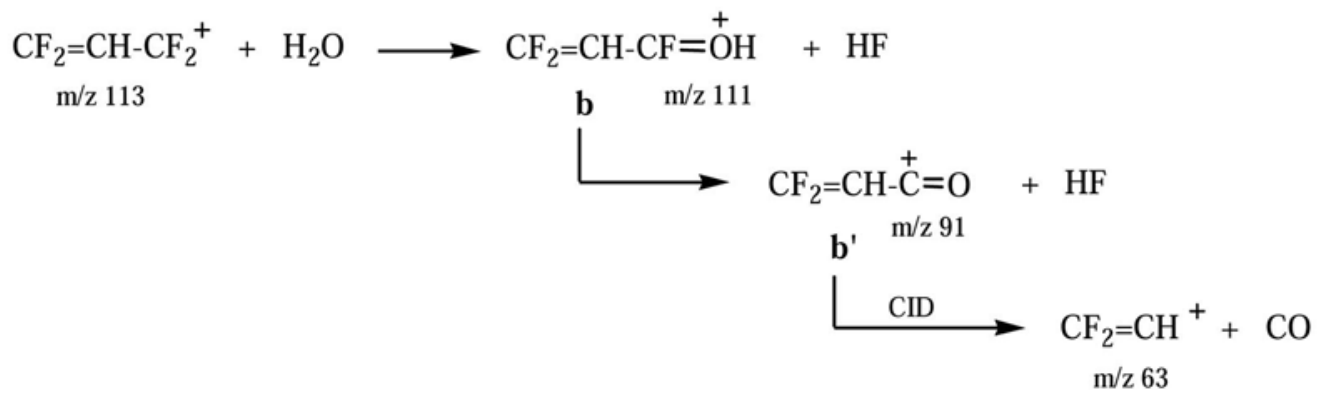

Scheme 6. Rationale for the processes occurring in APCI-MS of HFC-245fa in humid air. 
Table 2. Ionic products of the reactions of selected ions with HFE-7100, HFC-245fa and HFC-245ca (M) observed in APCI-TSQ experiments

\begin{tabular}{|c|c|c|c|c|c|c|}
\hline \multirow[b]{2}{*}{ M } & \multicolumn{6}{|c|}{ Reagent ion } \\
\hline & $\mathrm{O}_{2}^{-}$ & $\mathrm{O}_{2}^{-\cdot}\left(\mathrm{H}_{2} \mathrm{O}\right)$ & $\mathrm{O}_{3}^{-}$ & $\mathrm{NO}_{2}^{-}$ & $\mathrm{NO}_{3}^{-}$ & $\mathrm{N}_{2} \mathrm{O}_{2}^{-}$ \\
\hline HFE-7100 & $\begin{array}{l}\mathrm{C}_{4} \mathrm{~F}_{9} \mathrm{O}^{-} \\
\mathrm{C}_{3} \mathrm{~F}_{7}^{-}\end{array}$ & $\mathrm{C}_{4} \mathrm{~F}_{9} \mathrm{O}^{-}$ & $\mathrm{C}_{4} \mathrm{~F}_{9} \mathrm{O}^{-}$ & $\mathrm{C}_{4} \mathrm{~F}_{9} \mathrm{O}^{-}$ & - & - \\
\hline HFC-245fa & $\begin{array}{l}\mathrm{O}_{2}^{-\cdot} \cdot(\mathrm{M}) \\
\mathrm{O}_{2}^{-\cdot} \cdot(\mathrm{M})_{2} \\
\mathrm{O}_{2}^{-} \cdot(\mathrm{HF}) \\
\mathrm{O}_{2}^{-\cdot} \cdot(\mathrm{HF})(\mathrm{M})\end{array}$ & $\begin{array}{l}\mathrm{O}_{2}^{-} \cdot(\mathrm{M}) \\
\mathrm{O}_{2}^{-} \cdot(\mathrm{M})_{2} \\
\mathrm{O}_{2}^{-} \cdot(\mathrm{HF}) \\
\mathrm{O}_{2}^{-} \cdot(\mathrm{HF})(\mathrm{M})\end{array}$ & $\begin{array}{l}\mathrm{O}_{3}^{-} \cdot(\mathrm{M}) \\
\mathrm{O}_{3}^{-} \cdot(\mathrm{M})_{2}\end{array}$ & $\mathrm{NO}_{2}^{-}(\mathrm{M})_{2}{ }^{\mathrm{a}}$ & $\mathrm{NO}_{3}^{-}(\mathrm{M})_{2}^{\mathrm{a}}$ & $\mathrm{N}_{2} \mathrm{O}_{2}^{-\cdot}(\mathrm{M})_{2}{ }^{\mathrm{a}}$ \\
\hline HFC-245ca & $\begin{array}{l}\mathrm{O}_{2}^{-\cdot} \cdot(\mathrm{M}) \\
\mathrm{O}_{2}^{-\cdot} \cdot(\mathrm{M})_{2} \\
\mathrm{~F}^{-\cdot} \cdot(\mathrm{HF}) \\
\mathrm{F}^{-\cdot}(\mathrm{HF})(\mathrm{M}) \\
\mathrm{F}^{-}(\mathrm{M}) \\
\mathrm{F}^{-}(\mathrm{M})_{2}\end{array}$ & $\begin{array}{l}\mathrm{O}_{2}^{-\cdot} \cdot(\mathrm{M}) \\
\mathrm{O}_{2}^{-\cdot} \cdot(\mathrm{M})_{2} \\
\mathrm{~F}^{-}(\mathrm{HF}) \\
\mathrm{F}^{-}(\mathrm{HF})(\mathrm{M}) \\
\mathrm{F}^{-}(\mathrm{M}) \\
\mathrm{F}^{-}(\mathrm{M})_{2}\end{array}$ & $\begin{array}{l}\mathrm{O}_{3}^{-}(\mathrm{M}) \\
\mathrm{O}_{3}^{--} \cdot(\mathrm{M})_{2}\end{array}$ & $\begin{array}{l}\mathrm{NO}_{2}^{-}(\mathrm{M}) \\
\mathrm{NO}_{2}^{-}(\mathrm{M})_{2}\end{array}$ & $\begin{array}{c}\mathrm{NO}_{3}^{-}(\mathrm{M}) \\
\mathrm{NO}_{3}^{-}(\mathrm{M})_{2}\end{array}$ & $\begin{array}{l}\mathrm{N}_{2} \mathrm{O}_{2}^{-\cdot} \cdot(\mathrm{M}) \\
\mathrm{N}_{2} \mathrm{O}_{2}^{-} \cdot(\mathrm{M})\end{array}$ \\
\hline
\end{tabular}

a Observed only at high pressure.

$\mathrm{V}_{\text {cone }}$ is $^{\circ}$ due ${ }^{\circ}$ to ${ }^{\circ} \mathrm{C}_{4} \mathrm{~F}_{9} \mathrm{O}^{-{ }^{\circ}}$ ions $^{\circ}(\mathrm{m} / \mathrm{z} 235)^{\circ}\left(\right.$ Figure $\left.^{\circ} 5 \mathrm{a}\right) .{ }^{\circ}$ U Upon increasing of $\mathrm{V}_{\text {cone, }}$ this species dissociates to the following product ions: $\mathrm{C}_{3} \mathrm{~F}_{7}^{-}(\mathrm{m} / \mathrm{z} 169), \mathrm{CF}_{3}^{-}(\mathrm{m} / \mathrm{z} 69)$, and $\mathrm{F}^{-}{ }^{\circ}(m / z \quad 19)^{\circ}$ (Figure $\left.5 \mathrm{~b}\right){ }^{\circ}{ }^{\circ} \mathrm{In}^{\circ}$ addition, ${ }^{\circ}$ the ${ }^{\circ}$ product $\mathrm{CH}_{3} \mathrm{OCF}_{2} \mathrm{CF}_{2}^{-}(\mathrm{m} / \mathrm{z} 131)$ is also seen.

The reactivity towards HFE-7100 of each of the major background negative ions produced by APCI of air was studied by means of selected ion/molecule reaction experiments performed with the APCI-triple quadrupole instrument. In these experiments $\mathrm{C}_{4} \mathrm{~F}_{9} \mathrm{O}^{-}$ions are observed as products of the reaction of HFE-7100 with $\mathrm{O}_{2}^{-\cdot}, \mathrm{O}_{2}^{-\cdot}\left(\mathrm{H}_{2} \mathrm{O}\right), \mathrm{O}_{3}^{-\cdot}$, and $\mathrm{NO}_{2}^{-}$ions. ${ }^{\circ} \mathrm{In}^{\circ}$ Figure $^{\circ} 6^{\circ}$ the spectrum of the reaction products of $\mathrm{O}_{3}^{-\cdot}$ with HFE-7100 is reported as an example. In contrast, no products were observed when $\mathrm{NO}_{3}^{-}$and $\mathrm{N}_{2} \mathrm{O}_{2}^{-}$were used as reactant ions. In the reaction of $\mathrm{O}_{2}^{--}$with HFE-7100, $\mathrm{C}_{3} \mathrm{~F}_{7}^{-}$ions are also formed. In order to establish whether such $\mathrm{C}_{3} \mathrm{~F}_{7}^{-}$ions are primary products formed in a parallel reaction of $\mathrm{O}_{2}^{-}$with $\mathrm{M}$ or are rather due to fragmentation of $\mathrm{C}_{4} \mathrm{~F}_{9} \mathrm{O}^{-}$ions, the following experiment was performed. HFE-7100 was ionized in the APCI source and the $\mathrm{C}_{4} \mathrm{~F}_{9} \mathrm{O}^{-}$ions thus produced were mass-selected with Q1 and subjected to collision induced dissociation in the collision cell of the triple quadrupole. $\mathrm{C}_{3} \mathrm{~F}_{7}^{-}$was the only fragmentation product observed in several experiments covering a large energy range $(80-160 \mathrm{eV})$. Based on these results, the $\mathrm{C}_{3} \mathrm{~F}_{7}^{-}$ions observed in the reaction of $\mathrm{O}_{2}^{-}$with $\mathrm{M}$ can be reasonably considered to be the products of fragmentation of the $\mathrm{C}_{4} \mathrm{~F}_{9} \mathrm{O}^{-}$primary product ions.

The electron affinity of HFE-7100 is not known, but dissociative electron transfer seems to be the most probable way for the formation of $\mathrm{C}_{4} \mathrm{~F}_{9} \mathrm{O}^{-}$ions in the reactions with background anions $\mathrm{B}^{-}$(eq 2). The observation of $\mathrm{C}_{3} \mathrm{~F}_{7}^{-}$product ions only in the reaction of $\mathrm{M}$ with $\mathrm{O}_{2}^{-\cdot}$ is consistent with the fact that the electron affinity of $\mathrm{O}_{2}^{--}$is the lowest one among the reactive background ions $\left(\mathrm{O}_{2}^{-}: 0.45 \mathrm{eV} ; \mathrm{NO}_{2}^{-}: 2.27 \mathrm{eV} ; \mathrm{O}_{3}^{-}: 2.10 \mathrm{eV}\right.$ [12]). ${ }^{\circ}$ Thus, ${ }^{\circ}$ when ${ }^{\circ} \mathrm{B}^{-}{ }^{\circ}$ is ${ }^{\circ} \mathrm{O}_{2}^{-\cdot}$, reaction (2) is the most exothermic and forms $\mathrm{C}_{4} \mathrm{~F}_{9} \mathrm{O}^{-}$ions with an energy content sufficient to dissociate to $\mathrm{C}_{3} \mathrm{~F}_{7}^{-}$via $\mathrm{CF}_{2}=\mathrm{O}$ loss. Furthermore the electron affinity of the background ions which do not react with HFE-7100, i.e., $\mathrm{NO}_{3}^{-}$and

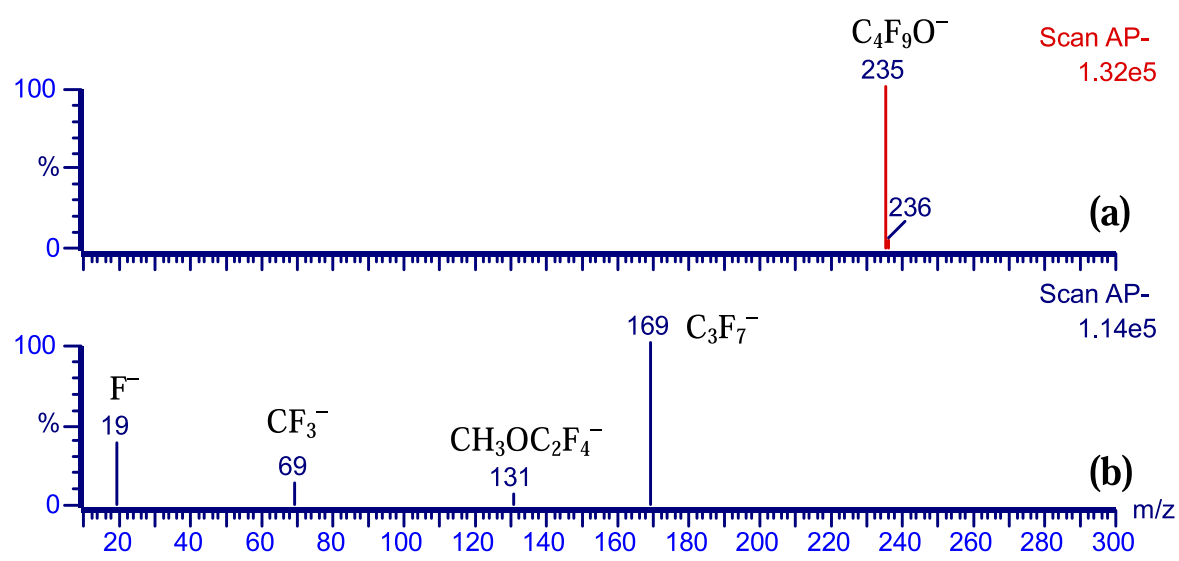

Figure 5. Negative APCI spectra of HFE-7100 in synthetic air recorded at $30{ }^{\circ} \mathrm{C}$ and (a) $\mathrm{V}_{\text {cone }}=1 \mathrm{~V}$, (b) $\mathrm{V}_{\text {cone }}=70 \mathrm{~V}$. 


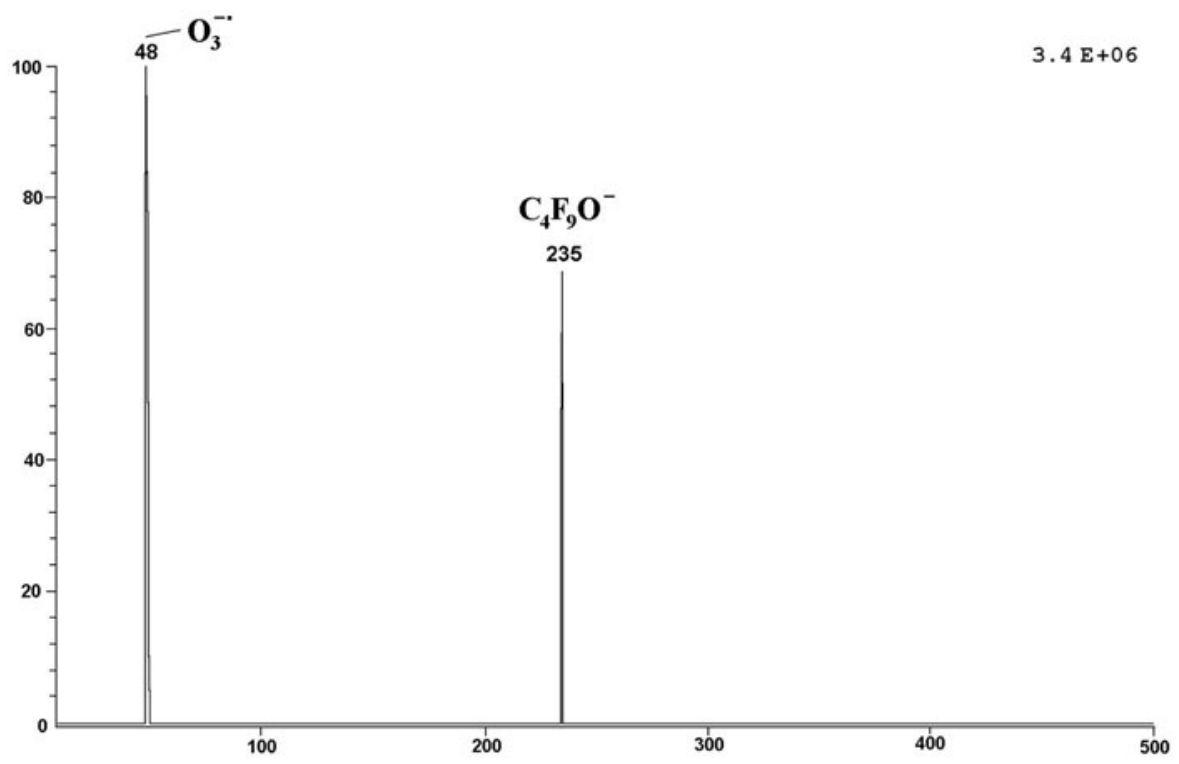

Figure 6. APCI-TSQ mass spectrum of the products of the reaction of $\mathrm{O}_{3}^{--}$with HFE-7100 at a nominal pressure of about $3 \cdot 10^{-4}$ Torr.

$\mathrm{N}_{2} \mathrm{O}_{2}^{-.}$, is the highest among the anions submitted to reaction $\left(\mathrm{NO}_{3}^{-}: 3.94 \mathrm{eV} ; \mathrm{N}_{2} \mathrm{O}_{2}^{-}: 2.93^{\circ} \mathrm{eV}^{\circ}[12]\right)$.

$$
\mathrm{B}^{-}+\mathrm{CH}_{3}-\mathrm{O}-\mathrm{C}_{4} \mathrm{~F}_{9} \rightarrow \mathrm{B}+\mathrm{CH}_{3}+{ }^{-} \mathrm{OC}_{4} \mathrm{~F}_{9}
$$

The results of these ion/molecule reaction experiments conducted with the triple quadrupole allow us to infer the origin of $\mathrm{C}_{4} \mathrm{~F}_{9} \mathrm{O}^{-}$ions observed in the air plasma of the APCI source. The fact that under these conditions $\mathrm{C}_{3} \mathrm{~F}_{7}^{-}$ions are not observed at low values of $\mathrm{V}_{\text {cone }}\left(\right.$ Figure $^{\circ} 5 \mathrm{a}$ ), ${ }^{\circ}$ when ${ }^{\circ} \mathrm{O}_{2}^{-}$is the most abundant species of the background, is reasonably due to the higher efficiency of ion cooling via thermalizing collisions in the APCI ionization chamber with respect to the triple quadrupole collision cell, because of the considerably higher pressure.

\section{HFC-245fa (1,1,1,3,3-Pentafluoropropane)}

The negative APCI spectra of HFC-245fa (M) at $30^{\circ}$ and $300{ }^{\circ} \mathrm{C}$ are dominated by ion-neutral complexes with the $^{\circ}$ anions $^{\circ}$ of $^{\circ}$ the ${ }^{\circ}$ background ${ }^{\circ}\left(\right.$ Figure $^{\circ}$ 7)..$^{\circ}$ Ion-neutral complexes of $\mathrm{M}$ with $\mathrm{F}^{-}$and $\mathrm{F}^{-}(\mathrm{HF})$ are also observed, sometimes including water molecules, $\mathrm{F}^{-}(\mathrm{HF})\left(\mathrm{H}_{2} \mathrm{O}\right)_{\mathrm{m}}(\mathrm{M})_{\mathrm{n}}$. Upon increasing $\mathrm{V}_{\text {cone }}$ consecutive losses of $\mathrm{M}$ and $\mathrm{H}_{2} \mathrm{O}$ take place, leading to $\mathrm{F}^{-}(\mathrm{HF}$ ) (at $\mathrm{V}_{\text {cone }}$ ca. $30 \mathrm{~V}$ ) and eventually to the bare anion $\mathrm{F}^{-}$(at $\mathrm{V}_{\text {cone }}$ ca. $\left.70 \mathrm{~V}\right)$. The formation of $\mathrm{F}^{-}(\mathrm{HF})_{\mathrm{n}}$ is common in wet atmospheres and has been attributed to clustermediated $^{\circ}$ reactions $^{\circ}[13] .{ }^{\circ}$ Another ${ }^{\circ}$ interesting ${ }^{\circ}$ species, detected in the spectrum at $\mathrm{V}_{\text {cone }}=20 \mathrm{~V}$, is an ion at $\mathrm{m} / \mathrm{z}$ 52 of composition $[\mathrm{H}, \mathrm{F}, 2 \mathrm{O}]$, the structure and origin of which are described below.

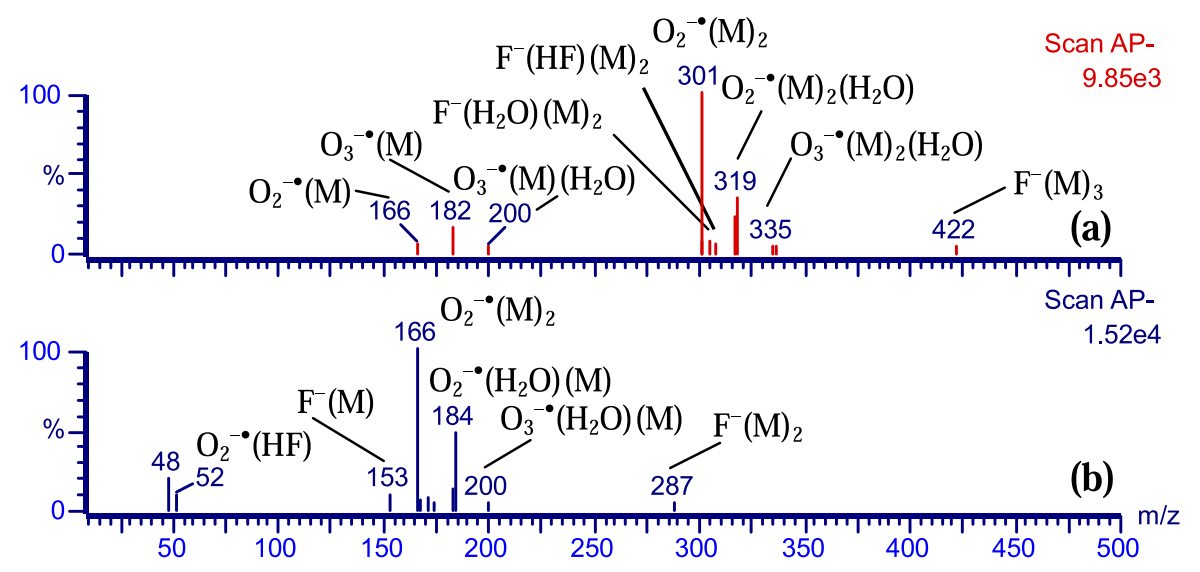

Figure 7. Negative APCI spectra of HFC-245fa in synthetic air recorded at $\mathrm{V}_{\text {cone }}=1 \mathrm{~V}$ and $300^{\circ} \mathrm{C}$. 


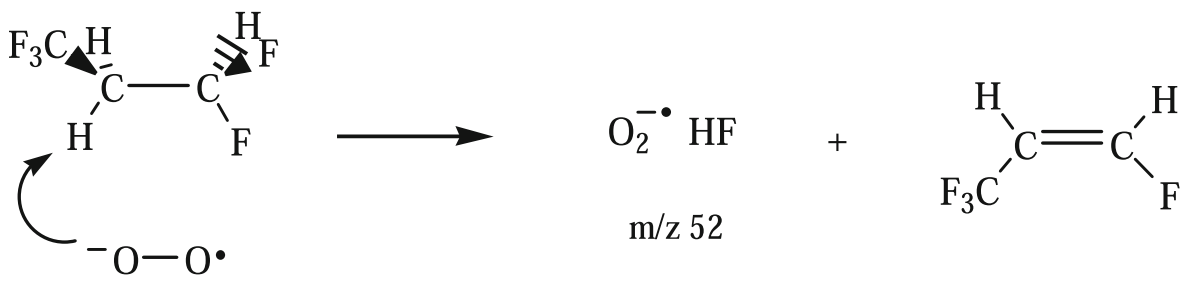

Scheme 7. Proposed mechanism for formation of $m / z 52$ in the reaction of HFC-245fa with $\mathrm{O}_{2}^{- \text {. }}$.

When allowed to selectively react in the triple quadrupole with each of the major anions formed in the air plasma, HFC-245fa confirmed its high association ability, already observed in the APCI source. Thus, reaction of HFC-245fa (M) with $\mathrm{B}^{-}\left(\mathrm{B}^{-}=\mathrm{O}_{2}^{-}, \mathrm{O}_{2}^{-\cdot}\left(\mathrm{H}_{2} \mathrm{O}\right), \mathrm{O}_{3}^{-.}\right.$, $\mathrm{NO}_{2}^{-}, \mathrm{NO}_{3}^{-}, \mathrm{N}_{2} \mathrm{O}_{2}^{-}$) inside the collision cell of the triple quadrupole produced the complexes $\mathrm{B}^{-}(\mathrm{M})_{\mathrm{n}}(\mathrm{n}=1,2)$ (Table ${ }^{\circ}$ ).

$\mathrm{As}^{\circ}$ mentioned $^{\circ}$ above $^{\circ}$ and $^{\circ}$ shown $^{\circ}$ in $^{\circ}$ Table $^{\circ} 2,{ }^{\circ}$ the reaction of $\mathrm{O}_{2}^{-}$with HFC-245fa forms an additional product with $m / z 52$, which we believe is best viewed as the ion/molecule complex $\mathrm{O}_{2}^{-\cdot}(\mathrm{HF})$. Scheme 7 shows a possible mechanism for the formation of such a product, which involves base induced HF 1,2-elimination. The structure $\mathrm{O}_{2}^{-\cdot}(\mathrm{HF})$ has been attributed to the product anion, based on the known proton affinities of $\mathrm{O}_{2}^{-}$. $\left(1476^{\circ} \mathrm{kJ} \cdot \mathrm{mol}^{-1^{\circ}}[12]\right)^{\circ}$ and $^{\circ} \mathrm{F}^{-}\left(1554^{\circ} \mathrm{kJ} \cdot \mathrm{mol}^{-1^{\circ}}[12]\right)^{\circ}$ and ${ }^{\circ}$ on its dissociation behavior. Thus, when formed in the APCI source of the triple quadrupole set-up and activated by collisions inside the collision cell, this ion dissociates to $\mathrm{O}_{2}^{-}$via $\mathrm{HF}$ elimination, in agreement with the greater thermochemical stability of $\mathrm{O}_{2}^{-\cdot}+\mathrm{HF}$ $\left(-316.8^{\circ} \mathrm{kJ} \cdot \mathrm{mol}^{-1^{\circ}}[12]\right)^{\circ}$ with $^{\circ}$ respect $^{\circ}$ to ${ }^{\circ} \mathrm{F}^{-}+\mathrm{O}_{2} \mathrm{H}$ $\left(-247.2^{\circ} \mathrm{kJ} \cdot \mathrm{mol}^{-1{ }^{\circ}}[12]\right)^{\circ}\left(\right.$ Figure $\left.^{\circ} 8\right)$.

In contrast to $\mathrm{O}_{2}^{-\cdot}(\mathrm{HF})$, which was observed both under APCI conditions and in the triple quadrupole, the species $\mathrm{F}^{-}(\mathrm{HF})(\mathrm{m} / \mathrm{z}$ 39) was never detected among the products of the reactions of HFC-245fa studied in the triple quadrupole. Interestingly, the isomeric pentafluoropropane HFC-245ca (1,1,2,2,3-pentafluoropropane) under the same experimental conditions produces $\mathrm{F}^{-}(\mathrm{HF})$ in the reaction with $\mathrm{O}_{2}^{-}$. The product $\mathrm{F}^{-}(\mathrm{HF})$ is indicated in the literature as the species with the strongest known hydrogen bond so far reported, recently $^{\circ}$ determined ${ }^{\circ}$ to $^{\circ} \mathrm{be}^{\circ} 191.7^{\circ} \mathrm{kJ} \cdot \mathrm{mol}^{-1^{\circ}}[14] . .^{\circ}$ Also, Morris $^{\circ}$ et $^{\circ}$ al..$^{\circ}[15]^{\circ}$ reported $^{\circ}$ the ${ }^{\circ}$ formation ${ }^{\circ}$ of $^{\circ} \mathrm{F}^{-}(\mathrm{HF})^{\circ}$ in the reaction of $\mathrm{O}_{2}^{-}$with a fluoropropane $\left(\mathrm{CF}_{3} \mathrm{CFHCF}_{3}\right)$ studied by the SIFT technique. $\mathrm{CO}_{2}$ and the ethyl radical $\mathrm{CF}_{2}-\mathrm{CFH}_{2}$ were indicated as the neutral products of this reaction.

\section{Conclusions}

The gas phase ion chemistry in air of HFE-7100 and HFC-245fa has been investigated by APCI-MS and by studying their reactions with selected atmospheric ions $\left(\mathrm{H}_{3} \mathrm{O}^{+}, \mathrm{O}_{2}^{+\cdot}, \mathrm{O}_{2}^{-\cdot}, \mathrm{O}_{3}^{--}, \mathrm{NO}_{2}^{-}, \mathrm{NO}_{3}^{-}, \mathrm{N}_{2} \mathrm{O}_{2}^{-\cdot}\right.$ and their hydrates) in a triple quadrupole mass spectrometer. The results of the two different approaches are complementary and produce an interesting map of the main ionic processes occurring in air plasmas by the fluorinated CFC-substitutes studied here. Interestingly, the reaction

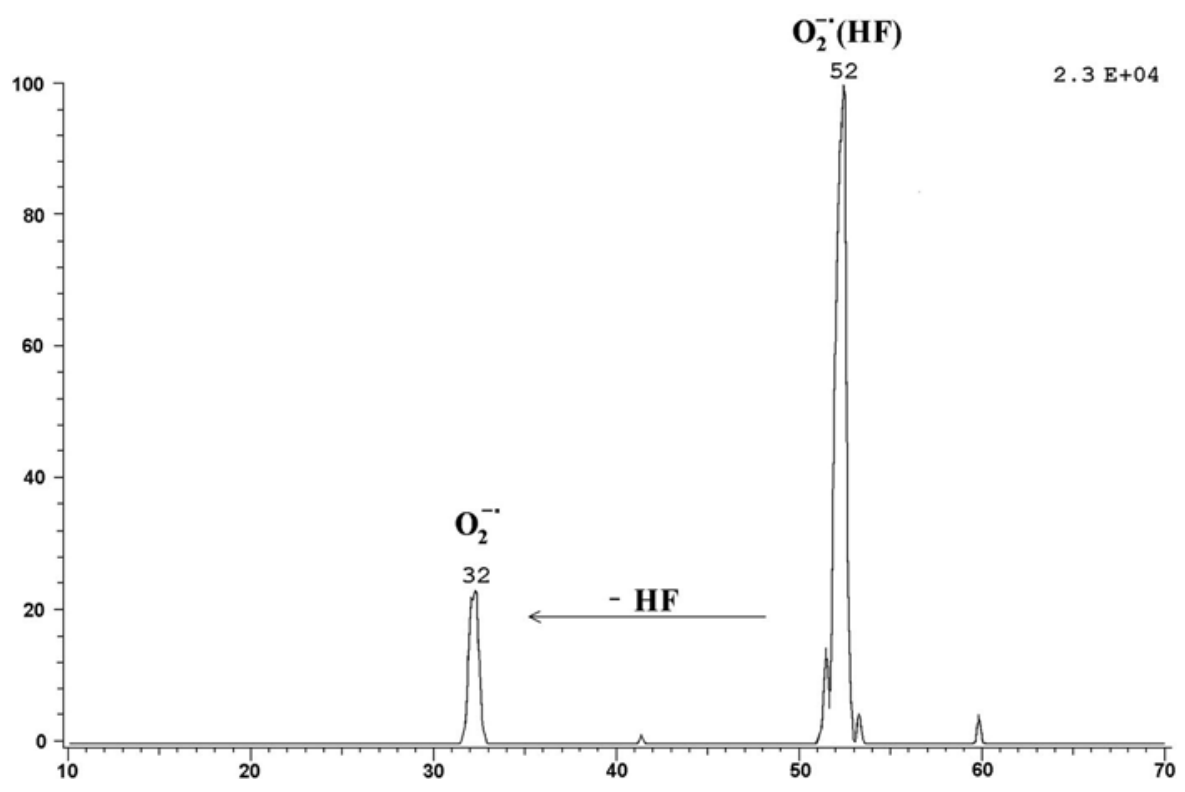

Figure 8. MS/MS spectrum of the ion $\mathrm{O}_{2}^{-\cdot}(\mathrm{HF})$ generated by APCI of HFC-245fa in the APCI-TSQ instrument. 
between HFC-245fa and $\mathrm{H}_{3} \mathrm{O}^{+}$does not lead to oxygenation of the fluorocarbon via $\mathrm{C}-\mathrm{O}$ bond formation, in contrast $^{\circ}$ with $^{\circ}$ what $^{\circ}$ was $^{\circ}$ found ${ }^{\circ}$ with ${ }^{\circ}$ other ${ }^{\circ} H F C s^{\circ}[6]^{\circ}$ and with HFE-7100. A common process is, instead, the condensation of fluorinated unsaturated cations with water followed by HF loss. This reaction leads to the oxidation of the compounds, so it can constitute an ionic pathway for the decomposition of these compounds by corona discharges.

Both HFE-7100 and HFC-245fa react with $\mathrm{O}_{2}^{-}$, the former by a dissociative electron transfer process, the latter by association and a base-induced elimination process, leading to the formation of the ion/molecule complex $\mathrm{O}_{2}^{-\cdot}(\mathrm{HF})$. The fluoropropane HFC-245ca, isomeric with HFC-245fa and studied for comparison, shows the same behavior of HFC-245fa in the reaction with $\mathrm{H}_{3} \mathrm{O}^{+}$ while it reacts differently with $\mathrm{O}_{2}^{--}$, giving rise to the formation of the complex $\mathrm{F}^{-}(\mathrm{HF})$. The position of the fluoro substitution is, therefore, a determinant in the interaction of $\mathrm{O}_{2}^{-\cdot}$ with the pentafluoropropanes.

Knowledge of the ion chemistry in air and of the oxidation processes initiated by the ions examined is of importance in the development of plasma-based technologies for the removal of these compounds from contaminated air as well as in the evaluation of their impact in the atmosphere.

\section{References}

1. Atmospheric Chemistry and Physics. From Air Pollution to Climate Change; Seinfeld, J. H.; Pandis, S. N., Eds.; John Wiley and Sons: New York, 1998.

2. (a) Vercammen, K. L. L.; Berezin, A. A.; Lox, F.; Chang, J. S. Nonthermal Plasma Techniques for the Reduction of VOC in Air Streams: A Critical Review. J. Adv. Oxid. Technol. 1997, 2, 312-329. (b) Odic, E.; Paradisi, C.; Rea, M.; Parissi, L.; Goldman, A.; Goldman, M. Treatment of Organic Pollulants by Corona Discharge Plasma. In The Modern Problems of Electrostatics with Applications in Environment Protection; NATO Science Series, 2. Environmental Security, Vol. LXIII, Inculet, I. I.; Tanasescu, F. T.; Cramariuc, R., Eds.; Kluwer Academic Publishers: Dordrecht, 1999; p 143.

3. Donò, A.; Paradisi, C.; Scorrano, G. Abatement of Volatile Organic Compounds by Corona Discharge. A Study of the Reactivity of Trichloroethylene Under Atmospheric Pressure Ionization Conditions. Rapid Commun. Mass Spectrom. 1997, 11, 1687-1694.

4. Nicoletti, A.; Paradisi, C.; Scorrano, G. Ion Chemistry of Chloroethanes in Air at Atmospheric Pressure. Rapid Commun. Mass. Spectrom. 2001, 15, 1904-1911.
5. Bosa, E.; Paradisi, C.; Scorrano, G. Positive and Negative GasPhase Ion Chemistry of Chlorofluorocarbons in Air at Atmospheric Pressure. Rapid Commun. Mass Spectrom. 2003, 17, 1-8.

6. Marotta, E.; Paradisi, C.; Scorrano, G. An APCI Study of the Positive and Negative Ion Chemistry of Hydrofluorocarbons 1,1-Difluoroethane (HFC-152a) and 1,1,1,2-Tetrafluoroethane (HFC-134a) and of Perfluoro- $n$-Hexane (FC-72) in Air Plasma at Atmospheric Pressure. J. Mass Spectrom. 2004, 39, 791-801.

7. Marotta, E.; Bosa, E.; Scorrano, G.; Paradisi, C. Positive and Negative Ion Chemistry of the Anesthetic Halothane (1Bromo-1-Chloro-2,2,2-Trifluoroethane) in Air Plasma at Atmospheric Pressure. Rapid Commun. Mass Spectrom. 2005, 19, 391-396.

8. Protection of Stratospheric Ozone: Notice 16 for Significant New Alternatives Policy Program. Environmental Protection Agency, U. S. Environmental Protection Agency, Washington, DC, U.S.A. Federal Register 2002, 67(56), 13272-13278.

9. Heck, A. J. R.; de Koning, L. J.; Nibbering, M. M. Gas-Phase Bimolecular Chemistry of Isomeric Cyclic Ethylenehalonium and $\alpha$-Haloethyl Cations. Org. Mass Spectrom. 1993, 28, 235-244.

10. (a) Carbini, M.; Conte, L.; Gambaretto, G.; Catinella, S.; Traldi, P. Mass Spectrometry of Some Fluorinated Alcohols. Org. Mass Spectrom. 1992, 27, 1248-1254. (b) Tajima, S.; Shirai, T.; Tobita, S.; Nibbering, N. M. M. Loss of Hydrogen Fluoride from Metastable $\mathrm{C}_{2} \mathrm{H}_{2} \mathrm{~F}_{3} \mathrm{O}^{+}$ions generated from some fluorinated aliphatic alcohols. Org. Mass Spectrom. 1993, 28, 473-474. (c) Várnai, P.; Nyulászi, L.; Veszprémi, T.; Vékey, K. Loss of Hydrogen Fluoride from $\mathrm{C}_{2} \mathrm{H}_{2} \mathrm{~F}_{3} \mathrm{O}^{+}$. A Theoretical Study of a Reaction Mechanism. Chem. Phys. Lett. 1995, 233, 340-346. (d) Sekiguchi, O.; Watanabe, D.; Nakajima, S.; Tajima, S.; Uggerud, E. Loss of $\mathrm{HF}$ from $\mathrm{C}_{2} \mathrm{H}_{4} \mathrm{FO}^{+}$Produced from 2-Hydroxy-2-Trifluoromethylpropanoic Acid Upon Electron Ionization. Int. J. Mass Spectrom. 2003, 222, 1-9.

11. Nguyen, V.; Mayer, P. S.; Morton, T. H. Intramolecular Fluorine Migration via Four-Member Cyclic Transition States. J. Org. Chem. 2000, 65, 8032-8040.

12. Lias, S. G. Ionization Energy Evaluation. In NIST Chemistry WebBook, NIST Standard Reference Database No. 69; Maillard, W. G.; Linstrom, P. J., Eds.; National Institute of Standards and Technology: ${ }^{\circ}$ Gaithersburg, ${ }^{\circ}$ MD; ${ }^{\circ}$ http://webbook.nist.gov / chemistry /, 2004 .

13. (a) Knighton, W. B.; Zook, D. R.; Grimsrud, E. P. ClusterAssisted Decomposition Reactions of the Molecular Anions of $\mathrm{SF}_{6}$ and $\mathrm{C}_{7} \mathrm{~F}_{14} . J$. Am. Soc. Mass Spectrom. 1990, 1, 372-381. (b) Arnold, S. T.; Viggiano, A. A. A Turbulent Ion Flow Tube Study of the Cluster-Mediated Reactions of $\mathrm{SF}_{6}^{-}$with $\mathrm{H}_{2} \mathrm{O}$, $\mathrm{CH}_{3} \mathrm{OH}$, and $\mathrm{C}_{2} \mathrm{H}_{5} \mathrm{OH}$ from 50 to 500 Torr. J. Phys. Chem. A 2001, 105, 3527-3531.

14. Wenthold, P. G.; Squires, R. R. Bond Dissociation Energies of $\mathrm{F}_{2}^{-}$and $\mathrm{HF}_{2}^{-}$. A Gas-Phase Experimental and G2 Theoretical Study. J. Phys. Chem. 1995, 99, 2002-2005.

15. Morris, R. A.; Viggiano, A. A.; Arnold, S. T.; Paulson, J. F. Reactions of Atmospheric Ions with Selected Hydrofluorocarbons. J. Phys. Chem. 1995, 99, 5992-5999. 